This document is published in:

Review of Economic Dynamics (2008), 11 (3), 584-613.

DOI: http://dx.doi.org/10.1016/j.red.2007.12.002

(C) 2007 Elsevier Inc. 


\title{
On the user cost and homeownership
}

\author{
Antonia Díaz $^{\text {a }}$, María José Luengo-Prado ${ }^{\mathrm{b}, *}$ \\ ${ }^{a}$ Universidad Carlos III, Spain \\ b Northeastern University, 301 Lake Hall, Boston, MA, USA
}

\begin{abstract}
This paper studies the differences in the cost of housing services for renters and homeowners and calculates the bias that results when we value owner-occupied housing services using a rental equivalence approach. Our framework is a life-cycle model with endogenous tenure choice with households facing idiosyncratic uninsurable earnings risk and housing price risk. We model houses as illiquid assets that provide collateral for loans. To analyze the impact of preferential housing taxation on the tenure choice and the bias, we consider a tax system that mimics that of the US economy. Namely, owner-occupied housing services are not taxed and mortgage interest payments are deductible. Through simulations, we show that a rental equivalence approach (relative to a user cost approach) overestimates the cost of housing services. The magnitude of the bias is very sensitive to both the income tax rate and the size of adjustment costs in the housing market.
\end{abstract}

JEL classification: E21; C80; E39

Keywords: Consumption; Durables; Down payments; Housing; User cost

\section{Introduction}

Housing services are an important component of aggregate consumption expenditure. In the 2006 National Income and Product Accounts (NIPA), housing services represent approximately 15 percent of aggregate consumption expenditures. A significant fraction of these services (about 80 percent) is acquired through homeownership (the remainder is obtained in the rental market). Therefore, it is important to pay attention to the valuation of owner-occupied housing services. The current practice by the Bureau of Labor Statistics is to use a rental equivalence method (see Verbrugge, 2003 and Poole et al., 2005 for a detailed description of this approach). Simply put, the Consumer Price Index is constructed assuming that the value of the services yielded by owner-occupied housing is the rental market value for the home. This approach is also used in constructing NIPA. As Prescott (1997) argues, this procedure is inconsistent with the principle that the effective price of a commodity should be its cost to the household consuming it (a user cost method). In the absence of frictions, both procedures-by asset pricing theory-should yield the same value for owner-occupied housing services. However, there are important frictions in the housing market. First, owner-occupied

\footnotetext{
* Corresponding author.

E-mail address: m.luengo@neu.edu (M.J. Luengo-Prado).
} 
housing services are not taxed (whereas rents of leased homes are) and interest mortgage payments are tax deductible. Second, houses are illiquid assets that also serve as collateral for loans. These frictions create a wedge between the user cost of owner-occupied housing services and the market rental price.

The purpose of this paper is to understand the differences between the user cost and the rental price for housing, and to give an estimate of the bias resulting from valuing owner-occupied housing services using the rental price. To this end, we start by constructing a model that mimics some key features of the US economy. Our model is a partial equilibrium life-cycle economy where households face uninsurable idiosyncratic labor risk and house price uncertainty. Households obtain utility from the consumption of nondurables and housing services. They can save either in the form of liquid financial assets or houses, which are subject to transaction costs. Houses can be financed minus a down payment and also serve as collateral for home equity loans. For simplicity, the only source of credit is collateralized loans on housing. We mimic the US tax system in a stylized way by assuming that houses are given preferential tax treatment: mortgage interest payments are deductible and services from owner-occupied housing are not taxed. ${ }^{1}$ Moreover, we assume that households are subject to idiosyncratic moving shocks that force them to sell their housing stock. This shock is meant to capture, in a stylized way, the effect of geographical mobility or changing needs due to variations in family size.

In our model and in reality, the housing tenure choice depends on several factors. On the one hand, buying a house insulates the consumption of housing services from variation in the rental price of housing. On the other hand, houses are illiquid assets and, hence, a very poor vehicle for shielding nondurable consumption against transitory income risk. Furthermore, homeowners' wealth is exposed to housing price risk whereas renters' wealth is not. Importantly, houses serve as collateral for loans but typically cannot be fully financed. In terms of taxation, owner-occupied housing services are not taxed and mortgage interest payments are deductible from the income tax base. Given this preferential tax treatment, households that are unlikely to move prefer buying to renting while younger households typically opt for renting because they must either accumulate a down payment or are more likely to move.

We construct a measure to price owner-occupied housing services, an ex post user cost based on the shadow price of housing for homeowners, which is the realized cost per dollar invested in housing stock. It is simply the present value of the sum of maintenance costs and property taxes (net of deductions), current and future transactions costs (appropriately discounted), the forgone return to home equity, and the cost of the mortgage (net of possible deductions) minus capital gains. Our user cost definition is different from that used by Poterba (1984) and Himmelberg et al. (2005) in two respects: (1) we include transaction costs and (2) we differentiate the cost of a dollar from own wealth invested in housing (given by the return to the alternative asset), and the cost of a borrowed dollar (the mortgage interest rate net of income tax deductions). Thus, user costs may vary across households because of differences in mortgage loan-to-value ratios as well as differences in the time of house purchase.

The user cost differs from the rental price of housing for a number of reasons. Most importantly, rental income from housing is taxable and its tax burden is internalized in the rental price, whereas services from owner-occupied housing are not. Even if the latter were taxed, the user cost and the rental price would be different. First, the existence of transaction costs implies that the user cost varies across households depending on the frequency of transactions. Second, the existence of spread in interest rates and the tax deductability of mortgage interest payments open a wedge between the forgone return to home equity and the cost of the mortgage. This implies that the user cost varies by household with mortgage loan-to-value ratios. Also, the divergence between the user cost and the rental price is further magnified when the present value of capital gains is included in the definition of user cost.

Through simulations, we calculate the bias resulting from valuing owner-occupied housing services using the rental price as opposed to the user cost. In our benchmark calibration, the bias is substantial: when using a rental equivalence approach we overestimate the cost of housing services by approximately 10.9 percent. Using our model, we are able to assess the quantitative importance of each component of our measure of the user cost. For instance, we find that the bias is very sensitive to the income tax rate. When we reduce the tax rate from 20 percent (our benchmark calibration value) to 15 percent, the bias goes down to 6.5 percent. Other important determinants of the bias are the magnitude of transaction costs (the higher the costs the lower the bias) and the existence of spread between the interest rate paid on mortgages and the interest rate on savings. With a 1 percent spread between both interest rates, the bias reaches the lowest of all scenarios considered, 2 percent. Importantly, we identify the tax exemption of owner-occupied housing

1 The preferential tax treatment on housing has been analyzed elsewhere. See, for example, Poterba (1984), Gahvari (1984), Skinner (1996) or Gervais (2002). 
services as the most important factor of distortion between the rental price and the user cost of housing, and, therefore, the bias.

Our paper builds on a growing literature examining tenure choice within a life-cycle framework. Ortalo-Magné and Rady (1999) study the relationship between financial conditions and the homeownership rate. Gervais (2002) focuses on the effects of taxation on tenure choice but abstracts from uncertainty, adjustment costs and the collateral role of housing. Ortalo-Magné and Rady (2002) demonstrate that homeownership is an effective way of isolating housing consumption against income risk. The studies most closely related to ours are Chambers et al. (2005), Li and Yao (2007), and Bajari et al. (2005). Chambers et al. (2005) study tenure choice in a general equilibrium model in which households can be renters and owners at the same time but abstract from price changes, taxation issues and home equity loans. Li and Yao (2007) also abstract from taxation issues and focus on the welfare effects of price appreciations. Bajari et al. (2005) focus on the welfare consequences of home price appreciation as well and show that price appreciation results in large wealth transfers across households and modest aggregate effects on welfare.

The remainder of this paper is organized as follows. Section 2 introduces our dynamic model and presents some theoretical results on household portfolio composition and tenure choice. The calibration of the model is presented in Section 3. In Section 4, we assess the quantitative importance of the bias introduced when imputing to owner-occupied housing services the rental price of housing. Conclusions are summarized in Section 5.

\section{The model economy}

We consider a life-cycle model economy where households derive utility from consumption of a nondurable good and housing services that can be obtained in a rental market or through homeownership. When purchasing a house, households must satisfy a down payment requirement. Also, accumulated housing equity above the down payment can be used as collateral for loans. For simplicity, no other form of credit is allowed. Furthermore, houses are illiquid assets subject to transaction costs. We model a tax system with preferential tax treatment on owner-occupied housing that mimics the US system. Households face idiosyncratic uninsurable earnings risk and uncertainty arising from changes in housing prices.

\subsection{Preferences, endowments and demography}

Households live for up to $T$ periods and face an exogenous probability of dying every period. They do not value leisure. During the first $R$ periods of life, their labor earnings are determined according to an idiosyncratic stochastic process. After period $R$, households retire and receive a pension. When a household dies, the household is replaced by a 'newborn'. Households are not altruistic toward their offspring. Since there are no annuity markets, households may die with positive wealth. We assume there is a government that taxes away all accidental bequests. That is, the next generations starts life with zero assets (we will discuss later the implications of allowing for accidental bequests).

Households derive utility from the consumption of a nondurable good and from the services provided by residential capital. Housing services can be obtained in the rental market or through homeownership. We assume one unit of housing stock (either rented or owned) provides one unit of housing services. Therefore, we write the per period utility of an individual of age $t$ born in period 0 as $u\left(c_{t}, s_{t}\right)$, where $c$ stands for nondurable consumption, and $s$ denotes housing services. In turn, we assume $s_{t}=x_{t} f_{t}+\left(1-x_{t}\right) h_{t}$, where $f$ denotes the housing stock rented in the market, and $h$ is the owned housing stock. Households cannot rent and be homeowners at the same time, so $x_{t}=1$ if the household is a renter (in period $t$ ), and 0 if an owner. The expected lifetime utility of a household born in period 0 is:

$$
E_{0} \sum_{t=0}^{T} \frac{1}{(1+\rho)^{t}} \zeta_{t} u\left(c_{t}, x_{t} f_{t}+\left(1-x_{t}\right) h_{t}\right)
$$

where $\rho \geqslant 0$ is the time discount rate and $\zeta_{t}$ is the probability of being alive at age $t$. 


\subsection{Market arrangements}

A household starts any given period $t$ with a stock of residential assets, $h_{t-1} \geqslant 0$, deposits, $d_{t-1} \geqslant 0$, and collateral debt (mortgage debt and home equity loans), $m_{t-1} \geqslant 0$. Deposits, meant to capture financial assets in general, earn a return $r_{t}^{d}$, while debt carries an interest payment at the rate $r_{t}^{m}$. There is no uncertainty about interest rates.

Households buy the stock of housing that renders services in period $t$ at the beginning of the period. The price of one unit of housing stock in period $t$ (in terms of nondurable consumption) is $q_{t}$, while the rental price of one unit of housing stock is $r_{t}^{f}$. When buying a house, households must satisfy a minimum down payment requirement, $\theta$, and houses serve as collateral for loans (home equity loans) with a maximum loan-to-value ratio of $(1-\theta){ }^{2}$ For simplicity, we assume that only collateralized credit on housing is available. This means that in all periods:

$$
m_{t} \leqslant(1-\theta) q_{t} h_{t}
$$

Thus, household net worth is always nonnegative and cannot be lower than a fraction $\theta$ of the house value for homeowners. Additionally, there is a link between outstanding debt and the home market value. Whenever a household is not moving and there is a decline in house prices, the household is required to decrease collateral debt to equal the fraction $(1-\theta)$ of the house value (i.e., a margin call). On the other hand, when prices go up, households can access the additional housing equity through refinancing or a home equity loan at no additional cost. Thus, households take all the capital gains and losses associated with changes in house prices. In reality, the burden of downward property prices, and to a lesser extent the benefits of higher prices (through refinancing and closing costs), are shared between financial institutions and households. ${ }^{3}$ However, this specification allows us to consider both down payment requirements and home equity loans without the need for modeling specific mortgage contracts or mortgage choice. ${ }^{4}$

Buying a house is costly. Buyers must pay a fraction $\kappa$ of the house value, which may be interpreted as transaction costs or sales taxes. Selling a house is also costly. A fraction $\chi$ of the house value is lost when sold, which may be interpreted as brokerage fees. These costs make houses a less liquid asset than deposits. Houses depreciate at the rate $\delta^{h}$. If full maintenance is done, the house does not depreciate. However, households have some flexibility regarding how much maintenance to do in a given period. Transaction costs are avoided if the household maintains the stock to a certain degree, i.e., $0 \leqslant h_{t-1}-h_{t} \leqslant \delta^{h} h_{t-1}$. Buying and selling costs are paid if $h_{t}<\left(1-\delta^{h}\right) h_{t-1}$, which indicates the household is downsizing, or if $h_{t}>h_{t-1}$, which means the household is trading up. ${ }^{5}$

In our model economy, households may want to sell their houses for various reasons. First, selling the stock is the only way to realize capital gains beyond the maximum loan-to-value ratio for home equity loans. Second, households may want to increase or downsize housing consumption throughout the life cycle, or may want to take advantage of relatively cheaper rental prices. Finally, households may need to liquidate this asset to prop up nondurable consumption after depleting their deposits and maxing out home equity loans. Additionally, we assume that households are subject to an idiosyncratic moving shock, $z_{t}$, that forces them to sell their house. This shock is meant to capture the effect of geographical mobility associated to job change or changing family needs (not modeled for simplicity), as well as unexpected events such as natural disasters.

We do not impose an age limit on credit availability. In other words, households can buy a house on credit, regardless of age, provided they pay the down payment. We assume that the event of death occurs before the price for next period is realized, so that when a household dies the house is liquidated at the previous period price.

\footnotetext{
2 We abstract from income requirements when purchasing houses. Many lenders follow the rule of thumb of " 3 times income" for mortgages. However, the empirical literature finds that wealth constraints are more important than income constraints when purchasing a home. See for example Linneman et al. (1997) or Quercia et al. (2000).

3 This assumption simplifies the computation of the model. See Li and Yao (2007) for an alternative model with refinancing costs.

4 See Campbell and Cocco (2003) for a discussion of optimal mortgage choice. Note we also abstract from the effects of unexpected inflation. In a world with fixed-rate mortgages and price uncertainty, buying a house may become even more attractive as households can guarantee a fixed nominal price of housing services.

5 Results are robust to alternative formulations of the adjustment costs such as pure maintenance or pure depreciation. Our specification which is in between the two is slightly easier to implement computationally with a discrete grid.
} 


\subsection{The government}

The government taxes income, $y$, allowing a deduction for interest payments on mortgages and home equity loans. The deduction percentage is denoted as $\tau_{m}$. The government also imposes a proportional local property tax on housing (at the rate $\tau_{h}$ ). This tax is fully deductible from income taxes. Moreover, imputed housing rents for homeowners are tax-free. Thus, we can write taxable income in period $t, y_{t}^{\tau}$, as:

$$
y_{t}^{\tau}=y_{t}-\tau_{m} r_{t}^{m} m_{t-1}-\tau_{h} q_{t} h_{t-1} .
$$

For simplicity, we assume proportional income taxation at the rate $\tau_{y}$. Also, the entire proceeds from taxation are used to finance government expenditures that do not affect individuals at the margin.

\subsection{The structure of uncertainty}

Apart from the sources of uncertainty already discussed (uncertainty about the time of death and the moving shock), households are subject to risk in labor earnings and house prices. We discuss each in turn.

For working-age households, labor earnings, $w_{t}$, are the product of permanent income and a transitory shock $\left(P_{t}\right.$ and $v_{t}$, respectively):

$$
w_{t}=P_{t} v_{t}, \quad P_{t}=P_{t-1} \gamma_{t} \epsilon_{t} .
$$

Under this specification, permanent income growth, $\Delta \log P_{t}$, is the sum of a non-stochastic life-cycle component $\log \gamma_{t}$ and a permanent shock, $\log \epsilon_{t} \sim N\left(-\frac{\sigma_{\epsilon}^{2}}{2}, \sigma_{\epsilon}^{2}\right)$, assumed to be specific to each household. The transitory shock is also idiosyncratic, and $\log v_{t} \sim N\left(-\frac{\sigma_{v}^{2}}{2}, \sigma_{v}^{2}\right)$. Retirees receive a pension proportional to permanent earnings in the last period of their working life. That is, for a household born at time $0, w_{t}=b P_{R}, \forall t>R .^{6}$

Housing prices are uncertain and following $\mathrm{Li}$ and Yao (2007), we assume that house price appreciation follows and i.i.d. normal process: $q_{t} / q_{t-1}-1=\varrho_{t}$, with $\varrho_{t} \sim N\left(\mu_{\varrho}, \sigma_{\varrho}^{2}\right)$. This specification implies that house price shocks are permanent. ${ }^{7}$ We assume house price shocks are household-specific.

\subsection{The household's problem}

Based on the previous discussion, the problem solved by a newborn at 0 can be written as:

$$
\max _{\left\{c_{t}, f_{t}, h_{t}, d_{t}, m_{t}, x_{t}\right\}_{t=0}^{T}} E_{0} \sum_{t=0}^{T} \frac{1}{(1+\rho)^{t}} \zeta_{t} u\left(c_{t}, x_{t} f_{t}+\left(1-x_{t}\right) h_{t}\right),
$$

subject to

$$
\begin{aligned}
& c_{t}+r_{t}^{f} f_{t}+d_{t}-m_{t}+\left(1+\Psi\left(h_{t}, h_{t-1}, z_{t}\right)\right) q_{t} h_{t}+\Gamma\left(h_{t}, h_{t-1}, z_{t}\right) q_{t}\left(1-\delta^{h}\right) h_{t-1} \\
& \quad \leqslant w_{t}+\left(1+r_{t}^{d}\right) d_{t-1}-\left(1+r_{t}^{m}\right) m_{t-1}+q_{t}\left(1-\delta_{h}-\tau_{h}\right) h_{t-1}-\tau_{y} y_{t}^{\tau}, \quad \forall t=0, \ldots, T ; \\
& w_{t}=P_{t} v_{t}, \quad P_{t}=P_{t-1} \gamma_{t} \epsilon_{t}, \quad \forall t \leqslant R ; \quad w_{t}=b P_{R}, \quad \forall t>R ; \\
& y_{t}^{\tau}=w_{t}+r_{t}^{d} d_{t-1}-\tau_{m} r_{t}^{m} m_{t-1}-\tau_{h} q_{t} h_{t-1}, \quad \forall t=0, \ldots, T ; \\
& m_{t} \leqslant(1-\theta) q_{t} h_{t}, \quad \forall t=0, \ldots, T-1, m_{T}=0 ; \\
& c_{t} \geqslant 0, f_{t} \geqslant 0, h_{t} \geqslant 0, d_{t} \geqslant 0, m_{t} \geqslant 0, x_{t} \in\{0,1\}, z_{t} \in\{0,1\}, \quad \forall t=0, \ldots, T ; \\
& q_{t+1}=\left(1+\varrho_{t+1}\right) q_{t}, \quad \forall t=0, \ldots, T ; \\
& \Gamma\left(h_{t}, h_{t-1}, z_{t}\right)= \begin{cases}0, & \text { if } 0 \leqslant h_{t-1}-h_{t} \leqslant \delta^{h} h_{t-1} \text { and } z_{t}=0, \quad \forall t=0, \ldots, T ; \\
\chi, & \text { otherwise, }\end{cases}
\end{aligned}
$$

6 This simplification is required for computational reasons and is common in the literature. See, for example, Gourinchas and Parker (2002).

7 The assumption is common in the literature (e.g., Cocco, 2005; Campbell and Cocco, 2003) and greatly simplifies the computation of the model by facilitating a renormalization of the household problem with fewer state variables. 


$$
\Psi\left(h_{t}, h_{t-1}, z_{t}\right)= \begin{cases}0, & \text { if } 0 \leqslant h_{t-1}-h_{t} \leqslant \delta^{h} h_{t-1} \text { and } z_{t}=0, \quad \forall t=0, \ldots, T . \\ \kappa, & \text { otherwise, }\end{cases}
$$

Eq. (6) is the budget constraint. Eq. (7) describes labor income for working-age households and the pension benefit for retirees. Eq. (8) spells out taxable income. Eq. (9) is the collateralized debt constraint. Eq. (10) contains nonnegativity constraints, and states that households cannot be renters and homeowners at the same time and face moving shocks. Eq. (11) captures the dynamics of housing prices. Finally, Eqs. (12) and (13) describe the nature of buying and selling costs in the housing market ( $\Psi$ and $\Gamma$, respectively). Adjustment costs are paid whenever households change the housing stock or are forced to move because of a moving shock.

\subsection{The composition of a household's portfolio}

Under our assumptions, it is possible to analytically determine under what conditions households maintain deposits and debt simultaneously. Let $\hat{r}_{t}^{d}=\left(1-\tau_{y}\right) r_{t}^{d}$ denote the after-tax return to deposits, and $\hat{r}_{t}^{m}=\left(1-\tau_{m} \tau_{y}\right) r_{t}^{m}$ the after-tax mortgage interest rate. Likewise, $\hat{\tau}_{h}$ is the effective property tax rate, $\hat{\tau}_{h}=\left(1-\tau_{y}\right) \tau_{h}$. There are two possible scenarios: no spread and full deductability (of mortgage interest on income taxes), and spread or partial deductability.

With no spread and full deductability, the after-tax interest rate on deposits is the same as the after-tax mortgage interest rate. Proposition 1 in Appendix A shows that constrained households only hold debt whereas the portfolio of unconstrained households cannot be determined (unless they are in the last period of their life, in which case they have no deposits). ${ }^{8}$ However, these households only care about their net position, $a=d-m$, where $a$ denotes net financial assets.

Proposition 2 in Appendix A proves that with less than full deductability or interest spread, households always prefer equity to debt financing of their houses. In other words, there is a complete segmentation of households: those who have debt do not hold deposits and vice versa. Obviously, some households could have neither deposits nor mortgages.

\section{Calibration}

Our calibration is constructed to reproduce three statistics from the Survey of Consumer Finances (hereafter SCF): the homeownership rate, the median wealth-to-earnings ratio for working-age households, and the median ratio of the house value to total wealth for homeowners (71 percent, 1.8 and 0.82 , respectively). In Appendix B, we summarize relevant data from the SCF and briefly describe how we construct these numbers, which are simple averages for six years of the SCF (1989, 1992, 1995, 1998, 2001 and 2004). To match the targets in different scenarios, we change three parameters while keeping all other parameters in the model fixed (the fixed parameters are calibrated using relevant data and described next). The parameters we vary are the discount rate, $\rho$, the weight of housing in the utility function, denoted by $1-\alpha$, and the value of the smallest house (relative to the annual value of permanent income) that homeowners can purchase, $\tilde{\tilde{h}} \cdot{ }^{9}$ The general strategy to calibrate all other parameters is to focus, whenever possible, on the empirical evidence for the median household.

\subsection{Preferences, endowments and demography}

For computational reasons, one period is two years. Households are born at age $24(i=1)$ and die at the maximum age of $83(i=30)$. The retirement age is $66(i=22)$. Survival probabilities are taken from the latest US Vital Statistics (for females in 2003), published by the National Center for Health Statistics. The implied fraction of working-age households is 75.55 percent, slightly lower than the fraction in the SCF, 78.64 percent. Most parameters are quoted in annual terms but are adjusted to a bi-annual frequency in our calculations.

For preferences over consumption of nondurable goods and housing services, we choose the non-separable utility function:

$$
u(c, x f+(1-x) h)=\frac{\left(c^{\alpha}(x f+(1-x) h)^{1-\alpha}\right)^{1-\sigma}}{1-\sigma} .
$$

\footnotetext{
8 In our computation of the model, we assume that households do not hold debt and deposits simultaneously.

9 See Appendix D for a description on how this relative minimum size is defined and its role.
} 
Parameters and matching ratios

\begin{tabular}{|c|c|c|c|c|c|c|c|c|c|c|}
\hline & \multicolumn{3}{|c|}{ Targeted ratios } & \multicolumn{4}{|c|}{ Endogenous ratios } & \multicolumn{3}{|c|}{ Parameters } \\
\hline & $\begin{array}{l}\text { Median } \\
W / E \\
\text { (workers) }\end{array}$ & $\begin{array}{l}\text { Median } \\
q H / W \\
\text { (homeowners) }\end{array}$ & $\begin{array}{l}\text { Home- } \\
\text { ownership } \\
\text { rate }\end{array}$ & $\begin{array}{l}\text { Agg. } \\
\frac{r^{f} H}{r^{f} H+r^{f} F}\end{array}$ & $\begin{array}{l}\text { Agg. } \\
\frac{q H}{q H+r^{f} F}\end{array}$ & $\begin{array}{l}\text { Moving } \\
\text { rate }\end{array}$ & $\begin{array}{l}\text { Mean } \\
A / W \\
\text { (all) }\end{array}$ & $\begin{array}{l}\text { Discount } \\
\text { rate }(\%)\end{array}$ & $1-\alpha$ & $\underline{\tilde{h}}$ \\
\hline Benchmark & $\begin{array}{l}1.80 \\
(0.018)\end{array}$ & $\begin{array}{l}0.82 \\
(0.003)\end{array}$ & $\begin{array}{c}0.71 \\
(0.003)\end{array}$ & $\begin{array}{l}0.81 \\
(0.003)\end{array}$ & $\begin{array}{l}0.97 \\
(0.000)\end{array}$ & $\begin{array}{l}0.13 \\
(0.002)\end{array}$ & $\begin{array}{l}0.29 \\
(0.002)\end{array}$ & 2.73 & 0.238 & 1.63 \\
\hline $\begin{array}{l}\text { Lower deduction } \\
\qquad\left(\tau_{m}=0.8\right)\end{array}$ & $\begin{array}{l}1.80 \\
(0.015)\end{array}$ & $\begin{array}{l}0.82 \\
(0.005)\end{array}$ & $\begin{array}{l}0.71 \\
(0.003)\end{array}$ & $\begin{array}{l}0.81 \\
(0.003)\end{array}$ & $\begin{array}{l}0.97 \\
(0.000)\end{array}$ & $\begin{array}{l}0.12 \\
(0.002)\end{array}$ & $\begin{array}{l}0.30 \\
(0.002)\end{array}$ & 2.75 & 0.244 & 1.60 \\
\hline $\begin{array}{l}\text { Lower tax } \\
\qquad\left(\tau_{y}=0.15\right)\end{array}$ & $\begin{array}{l}1.80 \\
(0.018)\end{array}$ & $\begin{array}{l}0.82 \\
(0.004)\end{array}$ & $\begin{array}{l}0.71 \\
(0.004)\end{array}$ & $\begin{array}{l}0.80 \\
(0.004)\end{array}$ & $\begin{array}{l}0.97 \\
(0.001)\end{array}$ & $\begin{array}{l}0.13 \\
(0.002)\end{array}$ & $\begin{array}{l}0.29 \\
(0.004)\end{array}$ & 3.26 & 0.254 & 1.45 \\
\hline $\begin{array}{l}\text { Higher tax } \\
\qquad\left(\tau_{y}=0.25\right)\end{array}$ & $\begin{array}{l}1.80 \\
(0.022)\end{array}$ & $\begin{array}{l}0.82 \\
(0.005)\end{array}$ & $\begin{array}{l}0.71 \\
(0.003)\end{array}$ & $\begin{array}{l}0.83 \\
(0.002)\end{array}$ & $\begin{array}{l}0.98 \\
(0.000)\end{array}$ & $\begin{array}{l}0.13 \\
(0.002)\end{array}$ & $\begin{array}{l}0.29 \\
(0.004)\end{array}$ & 2.18 & 0.229 & 1.67 \\
\hline $\begin{array}{l}\text { Higher cost } \\
\qquad(\chi=10 \%)\end{array}$ & $\begin{array}{l}1.80 \\
(0.017)\end{array}$ & $\begin{array}{l}0.82 \\
(0.004)\end{array}$ & $\begin{array}{l}0.71 \\
(0.004)\end{array}$ & $\begin{array}{l}0.80 \\
(0.003)\end{array}$ & $\begin{array}{l}0.97 \\
(0.001)\end{array}$ & $\begin{array}{l}0.11 \\
(0.002)\end{array}$ & $\begin{array}{l}0.27 \\
(0.005)\end{array}$ & 2.75 & 0.272 & 1.50 \\
\hline $\begin{array}{l}\text { Lower downpay. } \\
\qquad(\theta=10 \%)\end{array}$ & $\begin{array}{l}1.80 \\
(0.015)\end{array}$ & $\begin{array}{l}0.82 \\
(0.004)\end{array}$ & $\begin{array}{l}0.71 \\
(0.002)\end{array}$ & $\begin{array}{l}0.80 \\
(0.003)\end{array}$ & $\begin{array}{l}0.97 \\
(0.000)\end{array}$ & $\begin{array}{l}0.10 \\
(0.002)\end{array}$ & $\begin{array}{l}0.15 \\
(0.002)\end{array}$ & 2.63 & 0.24 & 1.69 \\
\hline Alternative mov. shock & $\begin{array}{l}1.80 \\
(0.018)\end{array}$ & $\begin{array}{l}0.82 \\
(0.003)\end{array}$ & $\begin{array}{l}0.71 \\
(0.003)\end{array}$ & $\begin{array}{l}0.80 \\
(0.003)\end{array}$ & $\begin{array}{l}0.97 \\
(0.005)\end{array}$ & $\begin{array}{l}0.14 \\
(0.003)\end{array}$ & $\begin{array}{l}0.22 \\
(0.005)\end{array}$ & 2.74 & 0.234 & 1.70 \\
\hline No moving shock & $\begin{array}{l}1.80 \\
(0.020)\end{array}$ & $\begin{array}{l}0.82 \\
(0.004)\end{array}$ & $\begin{array}{c}0.71 \\
(0.003)\end{array}$ & $\begin{array}{l}0.82 \\
(0.003)\end{array}$ & $\begin{array}{l}0.98 \\
(0.000)\end{array}$ & $\begin{array}{l}0.09 \\
(0.003)\end{array}$ & $\begin{array}{l}0.23 \\
(0.006)\end{array}$ & 2.81 & 0.21 & 1.72 \\
\hline $\begin{array}{l}\text { Lower interest } \\
\qquad\left(r^{d}=r^{m}=2.5 \%\right)\end{array}$ & $\begin{array}{l}1.80 \\
(0.019)\end{array}$ & $\begin{array}{l}0.82 \\
(0.005)\end{array}$ & $\begin{array}{l}0.71 \\
(0.003)\end{array}$ & $\begin{array}{l}0.79 \\
(0.003)\end{array}$ & $\begin{array}{l}0.98 \\
(0.000)\end{array}$ & $\begin{array}{l}0.12 \\
(0.002)\end{array}$ & $\begin{array}{l}0.30 \\
(0.002)\end{array}$ & 1.91 & 0.212 & 1.46 \\
\hline $\begin{array}{l}\text { Higher depreciation } \\
\qquad\left(\delta^{h}=3 \%\right)\end{array}$ & $\begin{array}{l}1.80 \\
(0.020)\end{array}$ & $\begin{array}{l}0.82 \\
(0.002)\end{array}$ & $\begin{array}{l}0.71 \\
(0.003)\end{array}$ & $\begin{array}{l}0.82 \\
(0.002)\end{array}$ & $\begin{array}{l}0.97 \\
(0.001)\end{array}$ & $\begin{array}{l}0.11 \\
(0.002)\end{array}$ & $\begin{array}{l}0.25 \\
(0.005)\end{array}$ & 2.72 & 0.281 & 1.78 \\
\hline $\begin{array}{l}\text { Spread } \\
\qquad\left(r^{m}=5 \%\right)\end{array}$ & $\begin{array}{l}1.80 \\
(0.018)\end{array}$ & $\begin{array}{l}0.82 \\
(0.005)\end{array}$ & $\begin{array}{l}0.71 \\
(0.003)\end{array}$ & $\begin{array}{l}0.80 \\
(0.003)\end{array}$ & $\begin{array}{l}0.97 \\
(0.001)\end{array}$ & $\begin{array}{l}0.12 \\
(0.002)\end{array}$ & $\begin{array}{l}0.32 \\
(0.004)\end{array}$ & 2.94 & 0.268 & 1.43 \\
\hline $\begin{array}{l}\text { Catastrophic shock } \\
\quad(p=1 \%)\end{array}$ & $\begin{array}{l}1.80 \\
(0.013)\end{array}$ & $\begin{array}{l}0.82 \\
(0.005)\end{array}$ & $\begin{array}{l}0.71 \\
(0.003)\end{array}$ & $\begin{array}{l}0.82 \\
(0.003)\end{array}$ & $\begin{array}{l}0.98 \\
(0.000)\end{array}$ & $\begin{array}{l}0.12 \\
(0.003)\end{array}$ & $\begin{array}{l}0.34 \\
(0.004)\end{array}$ & 2.99 & 0.234 & 1.57 \\
\hline Acc. bequests & $\begin{array}{l}1.80 \\
(0.017)\end{array}$ & $\begin{array}{l}0.85 \\
(0.007)\end{array}$ & $\begin{array}{l}0.73 \\
(0.003)\end{array}$ & $\begin{array}{l}0.81 \\
(0.003)\end{array}$ & $\begin{array}{l}0.97 \\
(0.000)\end{array}$ & $\begin{array}{l}0.13 \\
(0.003)\end{array}$ & $\begin{array}{l}0.25 \\
(0.004)\end{array}$ & 4.53 & 0.210 & 1.50 \\
\hline TAXSIM & $\begin{array}{l}1.80 \\
(0.022)\end{array}$ & $\begin{array}{c}0.82 \\
(0.006)\end{array}$ & $\begin{array}{c}0.71 \\
(0.003)\end{array}$ & $\begin{array}{l}0.84 \\
(0.002)\end{array}$ & $\begin{array}{l}0.98 \\
(0.000)\end{array}$ & $\begin{array}{l}0.12 \\
(0.002)\end{array}$ & $\begin{array}{l}0.30 \\
(0.004)\end{array}$ & 1.89 & 0.227 & 1.67 \\
\hline
\end{tabular}

Notes. $W$ is wealth, $E$ is earnings, $q H$ is the house value for homeowners, $H$ is the housing stock for homeowners, $F$ is the housing stock for renters, $A$ is net financial assets (deposits minus mortgages). The benchmark parameter values are as follows. Interest rates (deposits and mortgages): $r^{d}=r^{m}=4 \%$. Housing depreciation: $\delta^{h}=1.5 \%$. Taxes (income tax rate, mortgage deduction and property tax): $\tau_{y}=0.2, \tau_{m}=1$, $\tau_{h}=0$. Adjustment costs (buying and selling): $\kappa=2 \%, \chi=6 \%$. Moving shocks: age-dependent as described in the text. Pension replacement ratio $50 \%$. Income process (permanent and transitory shocks variances): $\sigma_{\epsilon}^{2}=0.01, \sigma_{v}^{2}=0.073$. Standard deviations across 100 samples in parentheses.

The risk aversion parameter is $\sigma=2.1-\alpha$ and the discount factor, $\rho$, are chosen so that the model delivers a median house to wealth ratio for homeowners equal to 0.82 , and a median wealth-to-earnings ratio of 1.8 , as in the data. In our benchmark scenario, $1-\alpha$ and $\rho$ are 0.238 and 2.73 , respectively (see Table 1 ).

We follow Cocco et al. (2005) in our labor earnings calibration. Using data from the Panel Study of Income Dynamics (PSID), the authors estimate the life-cycle profile of income, as well as the variance of permanent and transitory shocks for three different educational groups: no high school, high school and college. Depending on the SCF wave considered, the median household in the US has either a high school degree or just some college (see Appendix B, Table 6, for more details). We choose Cocco et al.'s (2005) estimates of the variance of permanent and transitory shocks for households whose head has a high school degree. In annual terms, $\sigma_{\epsilon}^{2}=0.01$, and $\sigma_{v}^{2}=0.073$. $^{10}$ For consistency, we also use their estimated growth rate of the non-stochastic life-cycle component of earnings for a household with a high school degree (see Cocco et al.'s Table 2).

In our model, retirees face no income uncertainty. Their pension is set to be 50 percent of permanent income in the last period of working life. Munnell and Soto (2005) report that in 2001, the median replacement rate for newly retired workers according to both the Health Retirement Survey and Social Security Administration data was about

10 These values are typical in the literature. See Storesletten et al. (2004). 
42 percent (higher for earnings-poor individuals and lower for earnings-rich individuals due to the progressivity of the system). On a household basis, Social Security benefits provide an average replacement rate of 44 percent, 58 percent for a couple with a non-working spouse and 41 percent for couples where both spouses work. For computational reasons, our replacement rate is based on the last working-period only (and earnings go down for older workers in our simulation), as opposed to life-time earnings. Also, we abstract from heterogeneity in household composition. Cocco et al. (2005), facing a similar computational constraint, use a replacement rate of 68 percent for workers with a high school degree. Using data from the PSID, they calculate the replacement rate as the ratio of average income for retirees in a given education group to average labor income in the last working year prior to retirement for that educational group (i.e., their rate is then a ratio of averages). In the end, we choose a 50 percent replacement rate, a figure within the estimates of these two studies.

To calibrate the moving shock, we use information on moving rates from the Current Population Survey (CPS). Respondents in the survey (a repeated cross-section) are asked every year if they were living in the same house one year ago. In some years, they are also asked if they were living in the same house five years ago. This allows us to calculate the one-year and five-year moving rates reported in Table 2. In 2005, 10 percent of respondents age 24 or older report moving since the previous year. Moving rates are lower for homeowners and decrease with age. Among movers, roughly 53 percent report moving for reasons other than housing (i.e., new job, family reasons, natural disasters, etc.). Also, the probability of moving is not independent across years (in Table 2, we can see that the fiveyear moving rate is not five times the one-year rate). Based on this information, we construct moving rates by age cohort. Since the moving shock in our model tries to capture reasons for moving related to job change, family needs, and unexpected events, we start with the yearly moving probabilities and multiply them by 0.53 . Also, since our model is calibrated so that one period is 2 years, we multiply the yearly probabilities by 1.8 to take into account the fact that moving probabilities are not independent across years. We also report results for an alternative calibration in which we use a bi-annual 10 percent exogenous moving probability for all working-age households and no moving shock for retirees (to roughly account for the declining moving rates by age). While the exact choice of moving shocks affects the life-cycle profiles of homeownership significantly, the bias that results when we value owner-occupied housing services using a rental equivalence approach is not affected greatly by the exact specification of moving shocks as long as the overall homeownership rate is calibrated to be the same.

To gain some intuition on what these moving shocks imply, we calculate that with a 10 percent bi-annual moving rate (and no other shocks), households at age 65 would own, on average, three different houses. This number is computed assuming that a household buys the first house at age 24 and stays a homeowner its entire life cycle. If we assume the probability of moving every five years is the one for the youngest household in Table 2, 73.7 percent, the expected number of owned houses at retirement is seven.

Table 2

Moving rates

\begin{tabular}{lllll}
\hline Age & \multicolumn{2}{l}{ One-year rate } & & Five-year rate \\
\cline { 2 - 4 } \cline { 2 - 4 } & All & Non-housing reasons & Homeowners & All \\
\hline $25-29$ & 0.259 & 0.127 & 0.195 & 0.737 \\
$30-34$ & 0.189 & 0.099 & 0.119 & 0.608 \\
$35-39$ & 0.129 & 0.071 & 0.082 & 0.469 \\
$40-44$ & 0.094 & 0.051 & 0.063 & 0.369 \\
$45-49$ & 0.069 & 0.039 & 0.037 & 0.292 \\
$50-54$ & 0.057 & 0.031 & 0.038 & 0.227 \\
$55-59$ & 0.052 & 0.028 & 0.035 & 0.229 \\
$60-64$ & 0.054 & 0.027 & 0.038 & 0.196 \\
$65-69$ & 0.039 & 0.023 & 0.030 & 0.156 \\
$70-74$ & 0.034 & 0.020 & 0.027 & 0.139 \\
$75-70$ & 0.030 & 0.015 & 0.017 & 0.118 \\
$80-84$ & 0.020 & 0.007 & 0.016 & 0.117 \\
$85+$ & 0.026 & 0.006 & 0.015 & 0.101 \\
Total & 0.100 & 0.053 & 0.060 & 0.356 \\
\hline
\end{tabular}

Notes. Authors own calculations using the 2005 Current Population Survey. The sample includes heads of household 24 and older. 


\subsection{Market arrangements}

We require a minimum down payment of 20 percent, slightly below the 25 percent average down payment for the period 1963-2001 reported by the Federal Housing Finance Board. Thus, individuals can borrow up to 80 percent of the value of the house. While in reality households may be able to acquire houses with lower down payments, it is also the case that these households face higher marginal borrowing costs (including a higher interest rate and the purchase of mortgage insurance). To keep the model tractable, the down payment parameter is the same for all consumers and the borrowing rate is not a function of $\theta$. Note that $(1-\theta)$ represents the maximum loan-to-value ratio for home equity loans, and there are no fees associated to obtaining collateral loans in the model. We also present results for a lower down payment in Section 4.

Regarding adjustment costs, Gruber and Martin (2003), using data from the Consumption Expenditure Survey (CEX), document that selling costs for housing can be up to 7 percent, while buying costs are around 2.5 percent. We set the selling cost equal to 6 percent, a typical realtor fee, and the buying cost to 2 percent, within the range of their estimates. Finally, in our benchmark calibration, we assume no spread in interest rates and set both the mortgage rate and the deposits rate to 4 percent in annual terms (the average real rate for 1967-2005 calculated in Díaz and Luengo-Prado, 2006). Note, also, that our deposits variable is intended to capture all financial assets (not just banking deposits), which is why we have chosen the non-spread case as our benchmark scenario. We relax this assumption in Section 4.

\subsection{Taxes}

In our benchmark economy, we assume mortgage payments are fully deductible, $\tau_{m}=1$, and $\tau_{h}=0$. We also assume that the marginal income tax rate does not vary with the level of income and that capital income is not subject to any further deductions (i.e., proportional taxation at a single rate). To calibrate the income tax rate, $\tau_{y}$, we use data on personal income and personal taxes from NIPA, as well as information from TAXSIM, the NBER tax calculator. ${ }^{11}$ For the period 1989-2004, personal taxes represent 12.47 percent of personal income in NIPA. As in Prescott (2004), we multiply this number by 1.6 to reflect the fact that marginal income tax rates are usually higher than average rates. 1.6 is the mean ratio of marginal income tax rates to average tax rates using TAXSIM (see Feenberg and Coutts, 1993 for details). The final number is 19.96 percent, which we approximate by using $\tau_{y}=0.20 .{ }^{12}$

For simplicity, we abstract from payroll taxes since leisure is not valued in our model and thus, labor income taxes only have income effects. The potential effect of payroll taxes is washed out by our calibration strategy which adjusts the discount rate to match the observed aggregate wealth-to-earnings ratio. Changes in the discount rate alter this aggregate ratio without affecting the distribution of assets across households. As a matter of fact, we could abstract completely from labor income taxation since what matters for the question posed in this paper is the fact that owner-occupied housing services are not taxed. Thus, the key tax rate is the rate at which rental housing is taxed, not necessarily the labor income tax rate.

\subsection{House prices}

Housing prices are assumed to follow the process $q_{t}=q_{t-1}\left(1+\varrho_{t}\right)$, where $\varrho \sim N\left(\mu_{\varrho}, \sigma_{\varrho}^{2}\right) . \mu_{\varrho}=0$ and $\sigma_{\varrho}^{2}=$ 0.0132 (as in $\mathrm{Li}$ and Yao, 2007 and within the estimates of Goetzmann and Spiegel, 2000). For simplicity, we assume $\varrho_{t}$ is serially uncorrelated and also uncorrelated with the income shocks. The housing depreciation/maintenance cost rate, $\delta^{h}$, is set to 1.5 percent, within the estimates in Harding et al. (2007).

11 The TAXSIM data is available at http://www.nber.org/ taxsim/marginal-tax-rates/plusstate.html.

12 The income tax rate we use is very similar to that calibrated by Prescott (2004), 20.07 percent. In a previous version of this paper, we calibrated the income tax rate using information on government expenditures. Average government expenditure for the period 1954-2001 represented 21.25 percent of GDP, and 20.21 percent of taxable income, which was assumed to be GDP plus retirees' pensions. Thus, both calibration strategies result in similar income tax rates. 
An important part of our calibration is the rental price. Our model economy, being partial equilibrium, places no restriction on the rental price. However, we can use asset pricing theory and assume that the rental price is:

$$
r_{t}^{f}=\frac{q_{t}-E_{t}\left[\frac{1}{1+\hat{r}_{t+1}^{d}} q_{t+1}\left(1-\delta^{h}-\hat{\tau}_{h}\right)\right]}{1-\tau_{y}} .
$$

Expression (15) defines the after-tax rental price for housing. The rental price varies with house prices and incorporates the fact that housing rental income is taxable income. The specification can be interpreted as the user cost for a landlord who is not liquidity constrained, and who is not subject to adjustment costs. The landlord can deduct local housing taxes from income taxation but must pay income taxes on rental income. This calibration choice is also consistent with the estimates in Sinai and Souleles (2005), who find that the house price-to-rent ratio capitalizes expected future rents, as any other asset.

Our solution method and simulation strategy are explained in detail in Appendix D. We must stress that our model is not intended to study household portfolio composition in the presence of housing (see Flavin and Yamashita, 2002; Cocco, 2005; Yao and Zhang, 2005 for such models). Rather, our purpose is to reproduce the homeownership rate in the US so that we can compare the cost of housing services for renters and homeowners and determine if we are accurately measuring the cost of housing services when using a rental equivalence approach. To guarantee that our effort is useful (as we discuss in Section 4), we need to make sure we reproduce the homeownership rate in the US and that our calibration delivers reasonable life-cycle patterns. Next, we describe the life-cycle patterns of consumption, homeownership and wealth generated by our model in the benchmark case.

\subsection{The patterns of homeownership and wealth}

Fig. 1 depicts the evolution of some key variables throughout the life cycle in our benchmark scenario. All series are normalized by mean earnings. Panel (a) shows mean labor income (earnings for workers and pensions for retirees) and nondurable consumption. For working-age households, the life-cycle profile for earnings is the profile estimated by Cocco et al. (2005) for households with a high school degree. Earnings peak at age $47 .{ }^{13}$ For retirees, the pension replacement ratio is calibrated to be 50 percent of permanent earnings in the last working period. Our model produces a hump-shaped nondurable consumption profile with a peak around age 60 . The increase in nondurable consumption from age 24 to the peak is about 130 percent ( 90 percent for median consumption, which is not graphed). Fernández-Villaverde and Krueger (2007), using data from the CEX, document that demographics-adjusted expenditure on nondurables peaks between ages 50 and 60 and that the percentage increase from age 24 to the peak is about 30 percent (see their Fig. 4.5). The steeper profile our model delivers may be due to the fact that we abstract from non-collateralized debt. The decrease in nondurable consumption from the peak to age 80 in our model is 15 percent, while it is about 30 percent in the data. Our less steep profile for older cohorts could be due to the fact that we do not consider specific work-related expenditures that may decline at retirement.

Panel (b) in Fig. 1 depicts mean wealth and its different components throughout the life cycle. Total wealth is humpshaped and peaks at ages 60-63 with a value of about 3.4 times mean earnings in the economy, declining rapidly afterwards. ${ }^{14}$ Since we do not allow for altruism in the model, total wealth is zero for those who reach the oldest possible age. Housing wealth (including collateralized debt) increases until age 52-55, then stays fairly constant until it begins to decrease at age 76, when the homeownership rate starts to decline. At the wealth peak, housing wealth represents 63 percent of total wealth. At age 27, (gross) housing wealth represents 205 percent of total wealth for homeowners, which means that on average young homeowners (barely 2 percent) are borrowing to buy their houses, and their mean loan-to-value ratio is about 51 percent $(1-1 / 2.05)$. Financial assets are close to zero until age 36, and reach a peak at the wealth peak, representing 36 percent of total wealth. Note financial assets become negative at age 72 as retirees take advantage of reverse mortgages.

The targets of our calibration are the overall homeownership rate in the US, the median wealth-to-earnings ratio for working-age households, and the median house value to total wealth ratio for homeowners (71 percent, 1.8 and 0.82 , respectively). Fig. 2 plots the life-cycle patterns of these three variables against data from the SCF (averages

13 The shape is similar to that of the earnings process used by Fernández-Villaverde and Krueger (2007).

14 The peak is reasonable, see Fig. 4 in Appendix B for evidence from the SCF. 


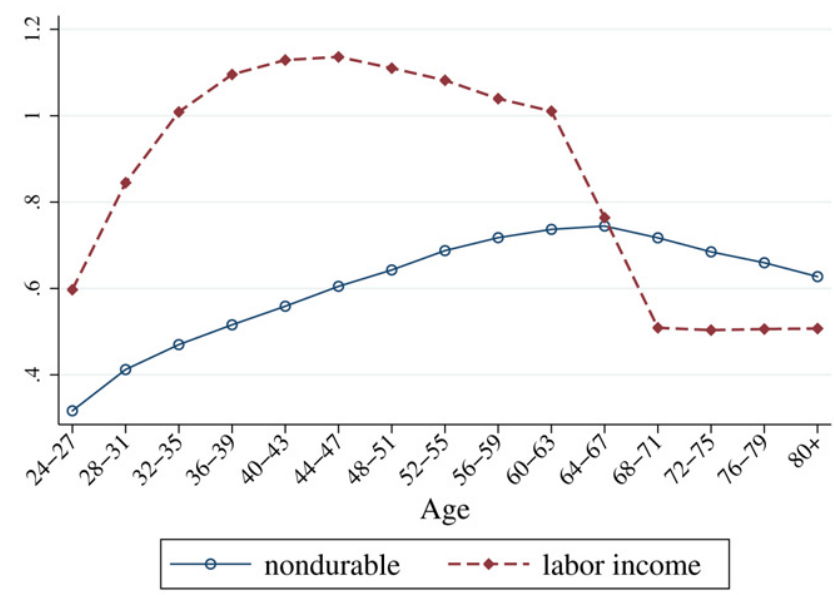

(a) Income and consumption

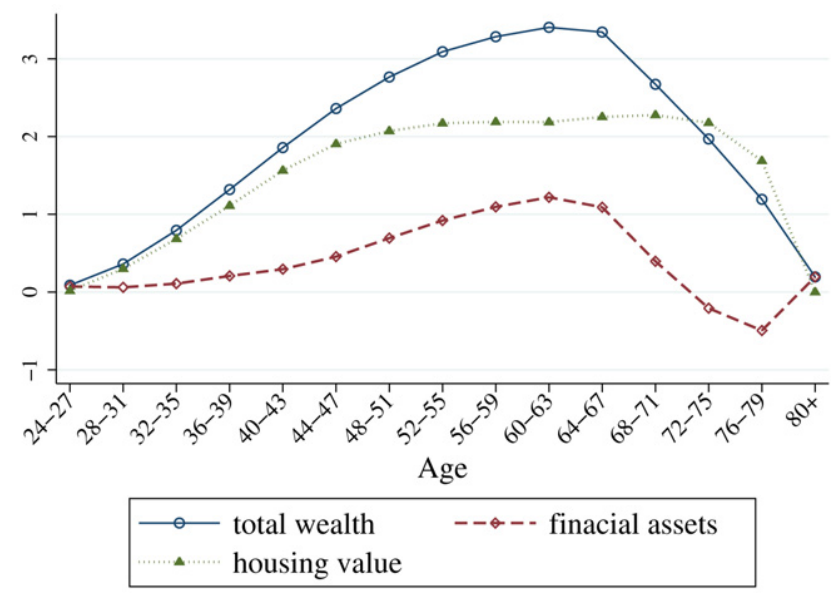

(b) Wealth

Fig. 1. Life-cycle profiles. The benchmark case.

from 1989 to 2004). The median wealth-to-earnings ratio in the model—see panel (a)—follows the ratio in the data very closely until age 59 and diverges significantly thereafter, probably because we are not allowing for heterogeneity in retirement ages. Also, the ratio is slightly higher in the data for the youngest cohort (i.e., the simulated median household is poorer in the model when young). In our model, gross housing wealth is a higher fraction of total wealth than in the data for the oldest cohorts. The fact that we are abstracting from intergenerational altruism (i.e., older cohorts exhaust their assets as they age) may account for this divergence. Other possibilities are limited availability of reverse mortgages in real life or uncertainty about health expenses when old, which may result in higher liquid savings. Note we are overstating the house-to-wealth ratio for the youngest and oldest cohorts, which represent about 16.94 percent of the population. This may affect our estimate of the value of owner-occupied housing services and it is discussed in Section 4.

Panel (b) in Fig. 2 depicts the life-cycle profile of homeownership rates in our benchmark calibration and in the SCF. Although we can reproduce the average homeownership rate in the US, our model underestimates homeownership for ages 24 to 40 and overestimates homeownership rates for older cohorts with the exception of the eldest. In our benchmark calibration, the eldest cohort turns to renting in the last period of life to free forced housing equity in the form of the down payment. In the data, this is not the case perhaps because of altruism or uncertainty about the time of death. Our simulated young cohorts are poorer than in the data, which can explain their lower homeownership rates. Many possible explanations come to mind for the higher homeownership rates of middle-age cohorts. For example, we may simply be underestimating the amount of uncertainty faced by at least a proportion of these households, which 

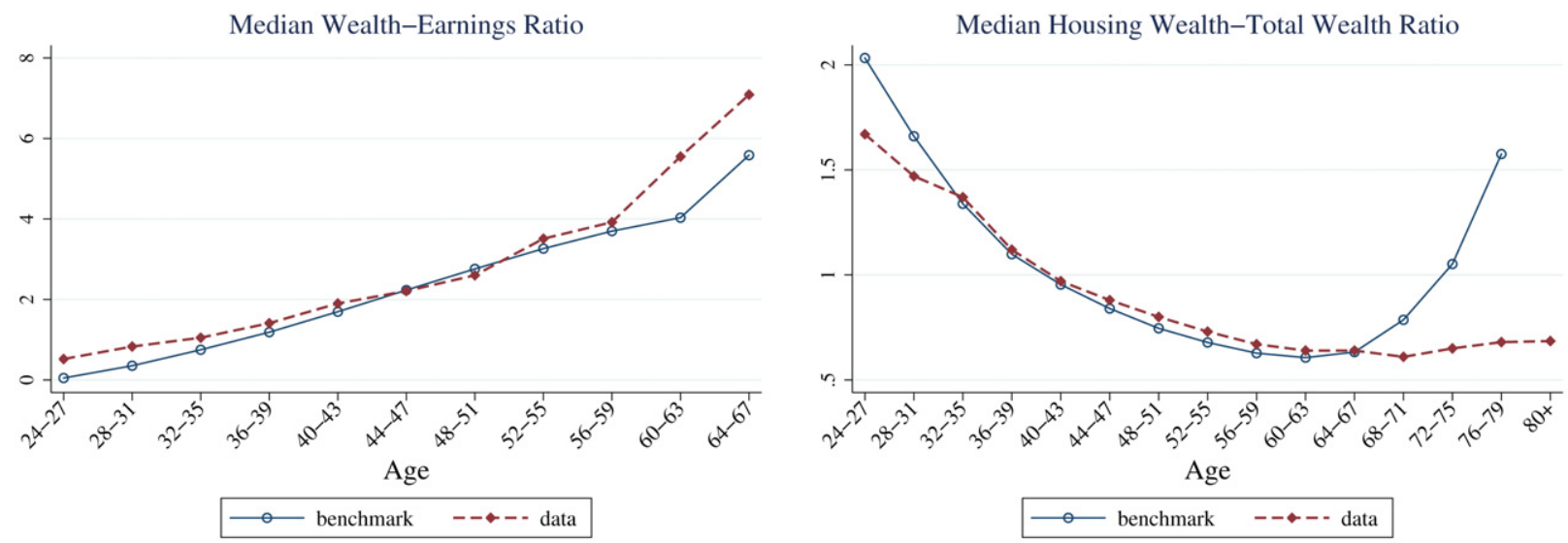

(a) Wealth and earnings

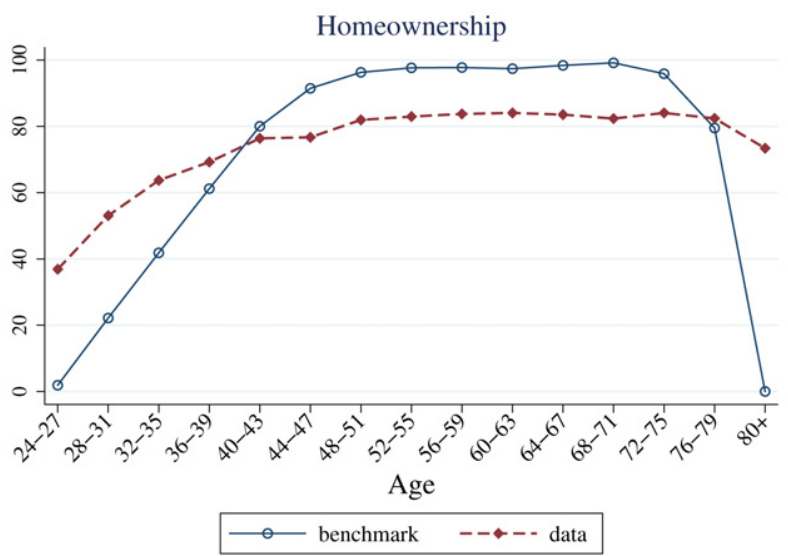

(b) Homeownership

Fig. 2. The benchmark and the data.

would make illiquid assets less attractive, or it could be the result of further heterogeneity not considered in our model. Overall, we think that the life-cycle patterns generated by our model approximate those in the US reasonable well.

\section{The value of housing services}

Our objective is to quantify the size of the bias introduced when using the rental price to value owner-occupied housing services. First, we need to provide a suitable measure for the cost of housing services for homeowners. In order to do this, we start by discussing how the shadow price of housing for homeowners differs from the shadow price of housing for renters in the presence of adjustment costs. Then, we define an ex post user cost measure based on the shadow price of housing which, in our view, is a more appropriate measure of the cost of owner-occupied housing services. Finally, we compute the bias resulting from using a rental price approach to value housing services (compared to a user cost approach) in our model.

\subsection{A price for owner-occupied housing services}

Owner-occupied housing services are not traded in the market and, therefore, there is no market price for them. The current procedure to compute the value of owner-occupied housing services is to use the rental price to value them. This procedure is inconsistent with the principle that the effective price of a commodity should be the cost of the commodity to the household consuming it. 
As an alternative, we could value these services using the shadow price the household assigns to them, as in Hall and Jorgenson (1967). To illustrate this procedure, we simplify our model economy and lump adjustment costs (selling and buying costs) together and assume that the adjustment cost function $\mathcal{C}\left(h_{t}, h_{t-1}, z_{t}\right)$ is a continuously differentiable convex function of the stock, taking the value zero when $h_{t}=\left(1-\delta^{h}\right) h_{t-1}$. Taking the return to deposits and the interest rate on mortgages as given, households that decide to purchase housing services in the market equate the marginal rate of substitution of housing services for nondurable consumption to the rental price of housing; that is, the shadow price of housing services is the rental price of housing:

$$
\frac{u_{s}\left(c_{t}, s_{t}\right)}{u_{c}\left(c_{t}, s_{t}\right)}=r_{t}^{f} .
$$

For homeowners, the shadow price of housing services is:

$$
\begin{aligned}
\frac{u_{s}\left(c_{t}, s_{t}\right)}{u_{c}\left(c_{t}, s_{t}\right)}= & q_{t} \quad 1+\mathcal{C}_{1}\left(h_{t}, h_{t-1}, z_{t}\right)-(1-\theta) \frac{\mu_{t}}{\lambda_{t}} \\
& -E_{t}\left[\left(\frac{\lambda_{t+1}}{\lambda_{t}} q_{t+1}\left(1-\delta^{h}-\hat{\tau}_{h}-\mathcal{C}_{2}\left(h_{t+1}, h_{t}, z_{t+1}\right)\right)\right],\right.
\end{aligned}
$$

where $\lambda_{t}$ is the Lagrange multiplier associated to the household's budget constraint given in (6), and $\mu_{t}$ is the multiplier associated to the liquidity constraint shown in (9). ${ }^{15} \mathcal{C}_{1}\left(h_{t}, h_{t-1}, z_{t}\right)$ is the partial derivative of the current adjustment cost with respect to $h_{t}$, and $\mathcal{C}_{2}\left(h_{t+1}, h_{t}, z_{t+1}\right)$ is the partial derivative of the adjustment cost in period $t+1$ with respect to $h_{t} .{ }^{16}$ This expression can be rewritten as:

$$
\begin{aligned}
\frac{u_{s}\left(c_{t}, s_{t}\right)}{u_{c}\left(c_{t}, s_{t}\right)}= & \mathcal{C}_{1}\left(h_{t}, h_{t-1}, z_{t}\right) q_{t}+\frac{\left[\left(\lambda_{t} / E_{t} \lambda_{t+1}\right)-1\right] q_{t}}{\lambda_{t} / E_{t} \lambda_{t+1}}-\frac{E_{t}\left(q_{t+1}-q_{t}\right)}{\lambda_{t} / E_{t} \lambda_{t+1}} \\
& +\frac{E_{t}\left(q_{t+1}\right)\left(\delta^{h}+\hat{\tau}_{h}+E_{t} \mathcal{C}_{2}\left(h_{t+1}, h_{t}, z_{t+1}\right)\right)}{\lambda_{t} / E_{t} \lambda_{t+1}}-(1-\theta) \frac{\mu_{t}}{\lambda_{t}} q_{t}-\xi_{t},
\end{aligned}
$$

which shows that the shadow price of owner-occupied housing comprises current transaction costs, $\mathcal{C}_{1}\left(h_{t}, h_{t-1}, z_{t}\right) q_{t}$, the present value of the forgone return to housing equity, $\left[\left(\lambda_{t} / E_{t} \lambda_{t+1}\right)-1\right] q_{t}$, the present value of future capital gains, $E_{t}\left(q_{t+1}-q_{t}\right)$ (with negative sign), the present value of the cost of maintenance, property taxes and future transaction costs, $E_{t}\left(q_{t+1}\right)\left(\delta^{h}+\hat{\tau}_{h}+E_{t} \mathcal{C}_{2}\left(h_{t+1}, h_{t}, z_{t+1}\right)\right)$, a term that captures all the opportunity costs incurred by buying housing stock, $q_{t}\left[(1-\theta) \mu_{t} / \lambda_{t}\right]$, and finally a term which comprises covariances, $\xi_{t}{ }^{17}$

If a household is not liquidity constrained $\left(\mu_{t}=0\right)$, expression (18) takes two different forms depending on whether there is spread and/or partial deductability of mortgage interest payments. In particular, with no spread and full deductability, $E_{t}\left(\lambda_{t+1} / \lambda_{t}\right)$ is equal to $1 /\left(1+\hat{r}_{t+1}^{d}\right)$ and expression (18) becomes:

$$
\begin{aligned}
\frac{u_{s}\left(c_{t}, s_{t}\right)}{u_{c}\left(c_{t}, s_{t}\right)}= & \mathcal{C}_{1}\left(h_{t}, h_{t-1}, z_{t}\right) q_{t}+\frac{\hat{r}_{t+1}^{d} q_{t}}{1+\hat{r}_{t+1}^{d}}-\frac{E_{t}\left(q_{t+1}-q_{t}\right)}{1+\hat{r}_{t+1}^{d}} \\
& +\frac{E_{t}\left(q_{t+1}\right)\left(\delta^{h}+\hat{\tau}_{h}+E_{t} \mathcal{C}_{2}\left(h_{t+1}, h_{t}, z_{t+1}\right)\right)}{1+\hat{r}_{t+1}^{d}}-\xi_{t} .
\end{aligned}
$$

If there is spread and/or partial deductability, the marginal rate of substitution for non-liquidity constrained households with debt is $E_{t}\left(\lambda_{t+1} / \lambda_{t}\right)=1 /\left(1+\hat{r}_{t+1}^{m}\right)$, and expression (18) becomes:

$$
\begin{aligned}
\frac{u_{s}\left(c_{t}, s_{t}\right)}{u_{c}\left(c_{t}, s_{t}\right)}= & \mathcal{C}_{1}\left(h_{t}, h_{t-1}, z_{t}\right) q_{t}+\frac{\hat{r}_{t+1}^{m} q_{t}}{1+\hat{r}_{t+1}^{m}}-\frac{E_{t}\left(q_{t+1}-q_{t}\right)}{1+\hat{r}_{t+1}^{m}} \\
& +\frac{E_{t}\left(q_{t+1}\right)\left(\delta^{h}+\hat{\tau}_{h}+E_{t} \mathcal{C}_{2}\left(h_{t+1}, h_{t}, z_{t+1}\right)\right)}{1+\hat{r}_{t+1}^{m}}-\xi_{t} .
\end{aligned}
$$

\footnotetext{
15 The Euler equations associated to the household's problem are shown in Appendix A, Eqs. (29)-(32).

16 Specifically, $\mathcal{C}_{1}\left(h_{t}, h_{t-1}, z_{t}\right)=\Psi\left(h_{t}, h_{t-1}, z_{t}\right)+\Psi_{1}\left(h_{t}, h_{t-1}, z_{t}\right) h_{t}+\left(1-\delta^{h}\right) h_{t-1} \Gamma_{1}\left(h_{t}, h_{t-1}, z_{t}\right)$, and $\mathcal{C}_{2}\left(h_{t+1}, h_{t}, z_{t+1}\right)=$ $h_{t+1} \Psi_{2}\left(h_{t+1}, h_{t}, z_{t+1}\right)+\left(1-\delta^{h}\right) \Gamma\left(h_{t+1}, h_{t}, z_{t+1}\right)+\left(1-\delta^{h}\right) \Gamma_{2}\left(h_{t+1}, h_{t}, z_{t+1}\right) h_{t}$, where $\Psi_{i}\left(h_{t}, h_{t-1}, z_{t}\right)$ and $\Gamma_{i}\left(h_{t+1}, h_{t}, z_{t+1}\right)$ denote the partial derivative with respect to their $i$ th argument.

$17 \xi_{t}=\operatorname{cov}_{t}\left(\lambda_{t+1} / \lambda_{t}, q_{t+1}\right)\left(1-\delta^{h}-\hat{\tau}_{h}-E_{t} \mathcal{C}_{2}\left(h_{t+1}, h_{t}, z_{t+1}\right)\right)+\operatorname{cov}_{t}\left(\lambda_{t+1} / \lambda_{t}, q_{t+1} \mathcal{C}_{2}\left(h_{t+1}, h_{t}, z_{t+1}\right)\right)$.
} 
For households without debt the shadow price is given by expression (19). ${ }^{18}$ Even without adjustment costs, expressions (19) and (20) are not equal to the rental price of housing given in Eq. (15) because owner-occupied housing services are not taxed. The difference between the shadow price of rental units and the shadow price of owner-occupied housing services is further amplified by the fact that households may be liquidity constrained (when (9) is binding). In this case, the first order condition of the household's problem with respect to the size of the mortgage implies that $\mu_{t}$ must be equal to $\lambda_{t}-\left(1+\hat{r}_{t+1}^{m}\right) E_{t} \lambda_{t+1}$. After some algebra, expression (18) for a liquidity constrained household becomes:

$$
\begin{aligned}
\frac{u_{s}\left(c_{t}, s_{t}\right)}{u_{c}\left(c_{t}, s_{t}\right)}= & \mathcal{C}_{1}\left(h_{t}, h_{t-1}, z_{t}\right) q_{t}+\frac{\left[\theta\left(\lambda_{t} / E_{t} \lambda_{t+1}-1\right)+(1-\theta) \hat{r}_{t+1}^{m}\right] q_{t}}{\lambda_{t} / E_{t} \lambda_{t+1}}-\frac{E_{t}\left(q_{t+1}-q_{t}\right)}{\lambda_{t} / E_{t} \lambda_{t+1}} \\
& +\frac{E_{t}\left(q_{t+1}\right)\left(\delta^{h}+\hat{\tau}_{h}+E_{t} \mathcal{C}_{2}\left(h_{t+1}, h_{t}, z_{t+1}\right)\right)}{\lambda_{t} / E_{t} \lambda_{t+1}}-\xi_{t} .
\end{aligned}
$$

This expression tells us that the shadow price of housing services is equal to the sum of current transaction costs, the forgone return to the down payment, $\theta\left(\lambda_{t} / E_{t} \lambda_{t+1}\right)$, the cost of the mortgage interest payments, the expected capital loss plus the future cost of maintenance, transaction costs and taxes. Note the shadow price of owner-occupied housing for a liquidity constrained household varies with the level of income, as income affects the intertemporal marginal rate of substitution for nondurable consumption, $\lambda_{t} / E_{t} \lambda_{t+1}$.

In practice, this shadow price cannot be used to value services of owner-occupied housing easily. First, the shadow price is not well-defined when there are non-convex adjustment costs. Second, the existence of price uncertainty and liquidity constraints opens a wedge between the shadow price (used by the household to make the tenure choice decision) and the realized cost of housing. To put it simply: we may make saving decisions based on an expected return of, say, 10 percent, but if the actual return is 2 percent we record in our books the realized return of 2 percent, not the expected return of 10 percent. That is, in order to calculate the true cost of owner-occupied housing services, we look at the realized cost, not the expected cost used by households to make their optimal tenure decisions. This is why we think the proper way to capture the actual cost of owning is to use the present value of an ex post user cost (i.e., after uncertainty has been revealed) defined as follows:

$$
\begin{aligned}
u c_{t}= & \Psi\left(h_{t}, h_{t-1}, z_{t}\right) q_{t}+q_{t}\left[\frac{\left(1-\mathcal{M}_{t}\right) \hat{r}_{t+1}^{d}+\mathcal{M}_{t} \hat{r}_{t+1}^{m}}{1+\hat{r}_{t+1}^{d}}\right] \\
& -\frac{\left(q_{t+1}-q_{t}\right)}{1+\hat{r}_{t+1}^{d}}+\frac{q_{t+1}\left(\delta^{h}+\hat{\tau}_{h}+\Gamma\left(h_{t+1}, h_{t}, z_{t+1}\right)\left(1-\delta^{h}\right)\right)}{1+\hat{r}_{t+1}^{d}} .
\end{aligned}
$$

Note the correspondence between the shadow price shown in (21) and the user cost. The first component of our user cost is $\Psi\left(h_{t}, h_{t-1}, z_{t}\right) q_{t}$, the incurred buying cost. The second term, where $\mathcal{M}_{t}$ is the mortgage loan-to-value ratio, represents the forgone return of home equity. The third component, $\mathcal{M}_{t} q_{t} \hat{r}_{t+1}^{m}$, measures the cost of the mortgage. The fourth component is the accrued capital gain (with a negative sign, since it lowers the user cost). The fifth term reflects maintenance costs, selling costs and property taxes (net of deductions). The last four terms are discounted by the after-tax interest rate. A comparison of this expression to the rental price in Eq. (15) tells us that the difference between both measures depends on the interest rate spread, the distortion imposed by the fact that owner-occupied housing services are not taxed, the existence of adjustment costs, and the divergence between expected and actual capital gains/losses.

Our definition of user cost includes capital gains. As argued by Prescott (1997), Verbrugge (2003) and Poole et al. (2005), adding capital gains to the definition of the user cost violates the tradition of NIPA. That is, by having capital gains in the expression, we are including the investment component of housing, not just the cost of housing as a consumption good. Moreover, since owner-occupied housing services are not taxed, the divergence between the rental price and the user cost is magnified by the inclusion of capital gains. This is why we also report results using an alternative definition of the user cost that excludes the capital gains term in (22).

Also, our user cost definition is different from that used by Poterba (1984) and Himmelberg et al. (2005) in two respects: (1) we include transaction costs and (2) we differentiate the cost of a dollar from own wealth invested in

18 Throughout this paper we are assuming that there is no uncertainty regarding interest rates. 
housing (given by the return to the alternative asset), and the cost of a borrowed dollar (the mortgage interest rate net of income tax deductions). Thus, user costs may vary across households because of differences in mortgage loan-tovalue ratios as well as differences in the time of house purchase.

\subsection{The rental price vs. the user cost}

In order to understand how the user cost differs from the rental price, we first calculate the mean user cost and the rental price in our benchmark scenario (Table 3, the row labeled 'benchmark'). The (bi-annual) rental price is 11.2 percent, whereas the mean (bi-annual) user cost, a simple average across homeowners, is 9.7 percent, 13.4 percent lower. We also report the mean user cost ignoring adjustment costs, ignoring capital gains, and ignoring both adjustment costs and capital gains (columns (3)-(5) respectively). Without adjustment costs, the mean user cost is 8.9 percent, roughly 20 percent lower than the rental price. Capital gains do not affect the mean user cost since we assume this term is zero on average. ${ }^{19}$

To understand the main differences between the user cost and the rental price, let us consider a case with constant house prices and no buying costs. Combining Eqs. (15) and (22), the user cost for homeowner $i$ can be written as:

$$
u c^{i}=\left(1-\tau_{y}\right) r^{f}+\frac{\left(1-\tau_{y}\right)\left(\mathcal{M}^{i}\left(\hat{r}^{m}-\hat{r}^{d}\right)+\Gamma^{i}\right)}{\hat{r}^{d}+\delta^{h}+\hat{\tau}_{h}} r^{f},
$$

where $\mathcal{M}^{i}$ is the mortgage loan-to-value ratio for household $i$. With no selling costs $\left(\Gamma^{i}=0\right)$, and no spread and full deductability $\left(\hat{r}^{m}=\hat{r}^{d}\right)$, the user cost is the same for all homeowners and equal to $\left(1-\tau_{y}\right) r^{f}$. Thus, for a rental price equal to 11.2 percent and a 20 percent tax rate, the user cost according to (23) should be $8.92(0.8 \times 11.2)$, roughly what we obtain in our simulations when adjustment costs are ignored (see column (3) in Table 3 ). ${ }^{20}$ So the fact that owner-occupied housing services are not taxed explains a great part of the difference between the rental price and the user cost. Eq. (23) also shows that the user cost is higher (relative to the rental price) the lower the tax rate, the higher the selling cost, and the higher the after-tax mortgage interest rate. The after-tax rate on deposits and the depreciation rate affect both the user cost and the rental price, so one cannot just infer their effects from this simple comparison.

Table 3 also reports the standard deviation of the mean user cost across simulations (the figures within parenthesis) and its standard deviation within simulations (the figures in brackets). The standard deviation within simulations provides a measure of the dispersion of the user cost across homeowners. This is about 13.2 percent in the scenarios considered. Of course this dispersion depends on the amount of idiosyncratic uncertainty, the level of adjustment costs and the range of possible capital gains/losses. In our benchmark calibration, the highest user cost, 31.5 percent, corresponds to a household that bought a house last period and has to move in a period of price depreciation (note very few households fall in this category as households would avoid selling in periods of house depreciation if possible). The lowest user cost, -0.07 percent, is for a homeowner who does not pay transaction costs in a period of house price appreciation. ${ }^{21}$ Fig. 3 shows the distribution of the user cost in the benchmark case, as well as the mean user cost by age cohort. Note the user cost decreases with age (except for those in the last two periods of life) as households move less often. In our benchmark case, all households sell their houses at the very end of their life cycles (to free the down payment), which explains the sudden increase in the mean user cost observed in Fig. 3.

We conduct various exercises to determine how the difference between the mean user cost and the rental price varies with financial conditions, tax rates, interest rates, etc. In all cases, we recalibrate our economy so that it produces the same aggregates in the different scenarios considered. Table 1 shows how parameters need to be recalibrated in each case, as well as some additional aggregates that are not the target of our calibration such as the moving rate, the size of owner-occupied housing services relative to all housing services, and the median of the ratio of net financial assets

\footnotetext{
19 Himmelberg et al. (2005) calculate annual user costs for several cities that vary from a maximum of 7.1 percent for Pittsburgh to a minimum of 3.3 percent for San Jose. The median value is 5.2 percent. The average user cost in our benchmark scenario, 4.7 percent in annual terms, is just slightly lower.

20 The exact rental price is 0.11153 .

21 In the benchmark case (no spread and full deductability), the user cost takes on 12 different values. We use three house price shocks when solving the model. Capital gains can be positive, negative or zero. Then, some households pay adjustment costs, while others do not. Since we have both buying and selling cots, the total number of combinations is 12 (some households pay only buying cots, others only selling costs and few buying and selling costs at the same time).
} 
Table 3

The unit cost of housing services

\begin{tabular}{|c|c|c|c|c|c|}
\hline & \multirow{2}{*}{$\begin{array}{l}\text { Rental price } \\
\text { (1) }\end{array}$} & \multicolumn{4}{|c|}{ Mean user cost of owner-occupied housing } \\
\hline & & $\begin{array}{l}\text { Total } \\
\text { (2) }\end{array}$ & $\begin{array}{l}\text { No adj. costs } \\
\text { (3) }\end{array}$ & $\begin{array}{l}\text { No cap. gains } \\
\text { (4) }\end{array}$ & $\begin{array}{l}\text { No adj. cost nor } \\
\text { cap. gains } \\
\text { (5) }\end{array}$ \\
\hline Benchmark & $\begin{array}{c}0.112 \\
(0.000) \\
{[0.000]}\end{array}$ & $\begin{array}{c}0.097 \\
(0.001) \\
{[0.132]}\end{array}$ & $\begin{array}{c}0.089 \\
(0.001) \\
{[0.132]}\end{array}$ & $\begin{array}{c}0.097 \\
(0.000) \\
{[0.019]}\end{array}$ & $\begin{array}{c}0.089 \\
(0.000) \\
{[0.004]}\end{array}$ \\
\hline $\begin{array}{l}\text { Lower deduction } \\
\qquad\left(\tau_{m}=0.8\right)\end{array}$ & $\begin{array}{c}0.112 \\
(0.000) \\
{[0.000]}\end{array}$ & $\begin{array}{c}0.099 \\
(0.001) \\
{[0.132]}\end{array}$ & $\begin{array}{c}0.091 \\
(0.001) \\
{[0.132]}\end{array}$ & $\begin{array}{c}0.099 \\
(0.000) \\
{[0.019]}\end{array}$ & $\begin{array}{c}0.092 \\
(0.000) \\
{[0.004]}\end{array}$ \\
\hline $\begin{array}{l}\text { Lower tax } \\
\qquad\left(\tau_{y}=0.15\right)\end{array}$ & $\begin{array}{c}0.109 \\
(0.000) \\
{[0.000]}\end{array}$ & $\begin{array}{l}0.100 \\
(0.001) \\
{[0.131]}\end{array}$ & $\begin{array}{c}0.093 \\
(0.001) \\
{[0.131]}\end{array}$ & $\begin{array}{c}0.100 \\
(0.000) \\
{[0.019]}\end{array}$ & $\begin{array}{c}0.093 \\
(0.000) \\
{[0.004]}\end{array}$ \\
\hline $\begin{array}{l}\text { Higher tax } \\
\qquad\left(\tau_{y}=0.25\right)\end{array}$ & $\begin{array}{c}0.114 \\
(0.000) \\
{[0.000]}\end{array}$ & $\begin{array}{c}0.093 \\
(0.001) \\
{[0.132]}\end{array}$ & $\begin{array}{c}0.086 \\
(0.001) \\
{[0.132]}\end{array}$ & $\begin{array}{c}0.094 \\
(0.000) \\
{[0.019]}\end{array}$ & $\begin{array}{c}0.086 \\
(0.000) \\
{[0.004]}\end{array}$ \\
\hline $\begin{array}{l}\text { Higher cost } \\
\qquad(\chi=10 \%)\end{array}$ & $\begin{array}{c}0.112 \\
(0.000) \\
{[0.000]}\end{array}$ & $\begin{array}{l}0.100 \\
(0.001) \\
{[0.133]}\end{array}$ & $\begin{array}{c}0.089 \\
(0.001) \\
{[0.132]}\end{array}$ & $\begin{array}{c}0.100 \\
(0.000) \\
{[0.029]}\end{array}$ & $\begin{array}{c}0.089 \\
(0.000) \\
{[0.004]}\end{array}$ \\
\hline $\begin{array}{l}\text { Lower downpay. } \\
\qquad(\theta=10 \%)\end{array}$ & $\begin{array}{c}0.112 \\
(0.000) \\
{[0.000]}\end{array}$ & $\begin{array}{l}0.095 \\
(0.001) \\
{[0.132]}\end{array}$ & $\begin{array}{c}0.089 \\
(0.001) \\
{[0.132]}\end{array}$ & $\begin{array}{c}0.095 \\
(0.000) \\
{[0.017]}\end{array}$ & $\begin{array}{c}0.089 \\
(0.000) \\
{[0.004]}\end{array}$ \\
\hline Alternative mov. shock & $\begin{array}{c}0.112 \\
(0.000) \\
{[0.000]}\end{array}$ & $\begin{array}{c}0.097 \\
(0.001) \\
{[0.132]}\end{array}$ & $\begin{array}{c}0.089 \\
(0.001) \\
{[0.132]}\end{array}$ & $\begin{array}{c}0.097 \\
(0.000) \\
{[0.020]}\end{array}$ & $\begin{array}{c}0.089 \\
(0.000) \\
{[0.004]}\end{array}$ \\
\hline No moving shock & $\begin{array}{c}0.112 \\
(0.000) \\
{[0.000]}\end{array}$ & $\begin{array}{l}0.094 \\
(0.001) \\
{[0.131]}\end{array}$ & $\begin{array}{c}0.089 \\
(0.001) \\
{[0.132]}\end{array}$ & $\begin{array}{c}0.094 \\
(0.000) \\
{[0.016]}\end{array}$ & $\begin{array}{c}0.089 \\
(0.000) \\
{[0.004]}\end{array}$ \\
\hline $\begin{array}{l}\text { Lower interest } \\
\qquad\left(r^{d}=r^{m}=2.5 \%\right)\end{array}$ & $\begin{array}{c}0.084 \\
(0.000) \\
{[0.000]}\end{array}$ & $\begin{array}{l}0.075 \\
(0.001) \\
{[0.135]}\end{array}$ & $\begin{array}{c}0.067 \\
(0.001) \\
{[0.135]}\end{array}$ & $\begin{array}{c}0.075 \\
(0.000) \\
{[0.020]}\end{array}$ & $\begin{array}{c}0.068 \\
(0.000) \\
{[0.004]}\end{array}$ \\
\hline $\begin{array}{l}\text { Higher depreciation } \\
\qquad\left(\delta^{h}=3 \%\right)\end{array}$ & $\begin{array}{c}0.146 \\
(0.000) \\
{[0.000]}\end{array}$ & $\begin{array}{l}0.123 \\
(0.001) \\
{[0.128]}\end{array}$ & $\begin{array}{c}0.117 \\
(0.001) \\
{[0.128]}\end{array}$ & $\begin{array}{c}0.123 \\
(0.000) \\
{[0.019]}\end{array}$ & $\begin{array}{c}0.117 \\
(0.000) \\
{[0.008]}\end{array}$ \\
\hline $\begin{array}{l}\text { Spread } \\
\qquad\left(r^{m}=5 \%\right)\end{array}$ & $\begin{array}{c}0.112 \\
(0.000) \\
{[0.000]}\end{array}$ & $\begin{array}{l}0.109 \\
(0.001) \\
{[0.132]}\end{array}$ & $\begin{array}{c}0.101 \\
(0.001) \\
{[0.132]}\end{array}$ & $\begin{array}{c}0.109 \\
(0.000) \\
{[0.019]}\end{array}$ & $\begin{array}{c}0.101 \\
(0.000) \\
{[0.007]}\end{array}$ \\
\hline $\begin{array}{l}\text { Catastrophic shock } \\
\qquad(p=1 \%)\end{array}$ & $\begin{array}{c}0.112 \\
(0.000) \\
{[0.000]}\end{array}$ & $\begin{array}{l}0.097 \\
(0.001) \\
{[0.132]}\end{array}$ & $\begin{array}{c}0.089 \\
(0.001) \\
{[0.132]}\end{array}$ & $\begin{array}{c}0.097 \\
(0.000) \\
{[0.019]}\end{array}$ & $\begin{array}{c}0.089 \\
(0.000) \\
{[0.004]}\end{array}$ \\
\hline Acc. bequests & $\begin{array}{c}0.112 \\
(0.000) \\
{[0.000]}\end{array}$ & $\begin{array}{l}0.097 \\
(0.001) \\
{[0.132]}\end{array}$ & $\begin{array}{c}0.089 \\
(0.001) \\
{[0.132]}\end{array}$ & $\begin{array}{c}0.097 \\
(0.000) \\
{[0.019]}\end{array}$ & $\begin{array}{c}0.089 \\
(0.000) \\
{[0.004]}\end{array}$ \\
\hline TAXSIM & $\begin{array}{c}0.117 \\
(0.000) \\
{[0.000]}\end{array}$ & $\begin{array}{c}0.094 \\
(0.001) \\
{[0.133]}\end{array}$ & $\begin{array}{c}0.087 \\
(0.001) \\
{[0.133]}\end{array}$ & $\begin{array}{c}0.094 \\
(0.000) \\
{[0.019]}\end{array}$ & $\begin{array}{c}0.087 \\
(0.000) \\
{[0.004]}\end{array}$ \\
\hline
\end{tabular}

Notes. Standard deviation across simulations in parentheses. Within simulation standard deviation in brackets (mean across simulations). The latter standard deviation measures the variation of user costs across households.

over total wealth across households. Note that, since the homeownership rate is 71 percent, the median household is a homeowner.

The row labeled 'Lower deduction' in Table 3, shows the rental price and the user cost in the case in which mortgage interest payments are not fully deductible. The user cost rises slightly, from 9.7 percent in the benchmark case to 9.9 percent, while the rental price is unchanged. Although under partial deductability mortgages become more expensive, households respond by decreasing their debt holdings, thus the small change in the user cost. With a lower income tax rate (the row labeled 'lower tax'), the rental price decreases to 10.9 percent and the user cost increases to 10 percent, 


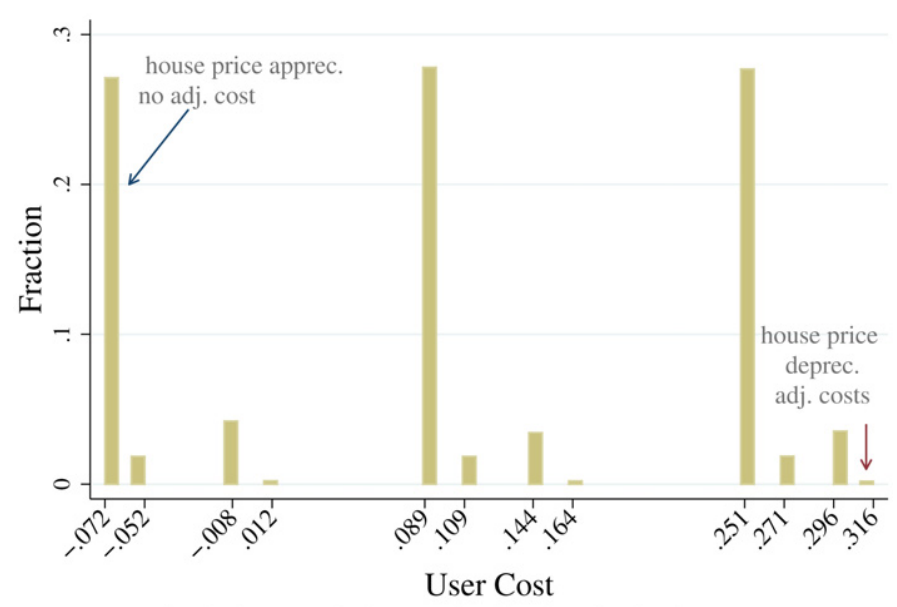

Note: for the 2 year period. Normalized by the price level

(a) User cost distribution

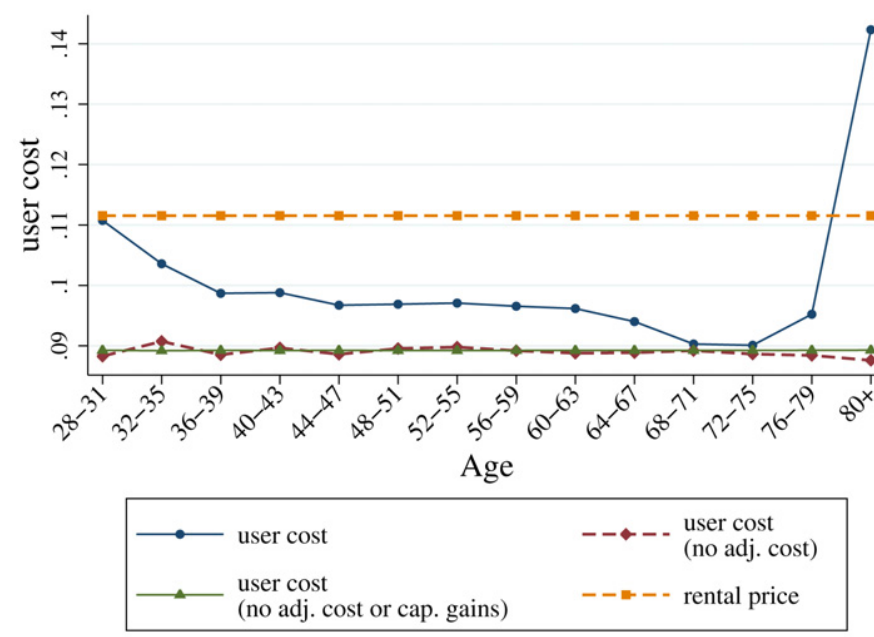

(b) Mean user cost by age

Fig. 3. The distribution of the user cost in the benchmark case.

thus the difference between the two shrinks. The opposite occurs when the tax rate increases. Since owner-occupied housing services are not taxed while housing services acquired through the rental market are, the higher the tax rate, the higher the difference between the two. Increasing the selling cost to $10 \%$ leaves the rental price unchanged but increases the user cost from 9.7 to 10 percent. The small change is due to the fact that households move less often with higher transaction costs, which dampens the effect of the higher cost. With a lower down payment $(\theta=0.1)$, the rental price is unchanged and the average user cost goes down slightly to 9.5 percent, the reason being that households again move less often as credit expands. As seen in Eq. (23), with no spread and full deductability the mortgage loanto-value ratio does not affect the mean user cost. However, fewer households have to sell their houses when facing negative income shocks with more collateral credit. Similarly, if we eliminate the moving shock, the average user cost decreases as households move less often. Our alternative simulation with a more parsimonious moving shock does not affect the user cost. Lower interest rates reduce both the rental price and the user cost, while a higher depreciation rate has the opposite effect. When we introduce spread, the user cost increases significantly to 10.9 percent as the cost of mortgages increases.

When households face a positive probability of receiving a transitory zero income shock, a catastrophic shock à la Carroll (1997), households save more in the form of liquid assets. Introducing such a shock with full deductibility and no spread does not affect the rental price nor the average user cost once parameters are recalibrated to produce 
the same aggregates. Note, however, that our simulated households must be more impatient for the wealth-to-earnings ratio to be the same. Furthermore, households must be able to buy smaller houses to obtain the same homeownership rate since households have a stronger preference for liquid assets in this case. Allowing for accidental bequests (in the benchmark economy they are taxed away) does not affect the rental price or the average user cost significantly either. However, in this case, households must be remarkably more impatient to obtain the same wealth-to-earnings ratio (the required discount rate is 4.5 percent as opposed to 2.73 percent in the benchmark case).

\subsubsection{An alternative calibration of tax rates}

It could be argued that the tax rate in our benchmark calibration does not represent the true tax burden for households since the tax system in the US is ex ante progressive and marginal and average rates could be very different (although we partially adjust for this fact in our benchmark calibration). Also, the different components of income are taxed at different rates and the key rate in our case is the rate at which rental housing services are taxed. To take this into account, we report results from an alternative calibration using TAXSIM. In this case, we allow for labor and capital income to be taxed at different rates. Appendix $\mathrm{C}$ describes the details of this calibration. The tax rate on labor income is $\tau_{w}=27.5$ percent, while the tax rate on capital income is $\tau_{d}=29.2$ percent. The deduction on mortgage payments is at the labor income rate, and $\tau_{m}=81.8$ percent. This implies an after-tax return on deposits $\hat{r}^{d}=\left(1-\tau_{d}\right) r^{d}=2.83$ percent, and an after-tax interest rate on mortgages $\hat{r}^{m}=\left(1-\tau_{w} \tau_{m}\right) r^{m}=3.1$ percent. The user cost is still defined as shown in (22). The expression for the rental rate shown in (15) changes slightly, since rental income from housing is taxed at the capital tax rate $\tau_{d}$.

As we can see in the row labeled 'TAXSIM' in Table 1, the discount rate must be significantly lower than in the benchmark calibration to match the median wealth-to-earnings ratio for working-age households. Also, the weight of housing services in the utility function, $1-\alpha$ is lower while the minimum house size, $\underline{\underline{h}}$, is larger. Furthermore, the value of owner-occupied housing services, as a fraction of total housing services, increases. These differences are happening because a larger tax on capital income has two effects. On one hand, it decreases savings and, therefore, the discount rate must be larger to obtain the same aggregate wealth-to-earnings ratio. On the other hand, the incentive to buy houses strengthens since the distortion due to fact that owner-occupied housing services are not taxed is magnified. Then, to obtain a given homeownership rate the minimum house size must be larger. Note that in this calibration mortgages are not fully deductability. When compared to the benchmark case, the rental price is slightly higher because of the higher tax rate (0.117 vs. 0.112), while the average user cost is just a bit lower (0.094 vs. 0.097). This may seem surprising as the increase in the tax rate at which rental income is taxed is substantial (from 20 to 29.2 percent). However, since mortgage interest payments are not fully deductible in this case, the spread between the after-tax interest rates on mortgages and deposits partially offsets the effect of taxation.

\subsection{The bias introduced when using a rental equivalence method}

In this section, we use the proposed user cost measure in (22) to estimate the bias in the value of aggregate housing services resulting from using a rental equivalence method. In general, the bias can be written as:

$$
b=\sum_{i \mid h^{i}>0} \frac{u c^{i}-r^{f}}{r^{f}} \eta^{i},
$$

where $u c^{i}$ is the user cost for homeowner $i$ and $\eta^{i}$ is the weight given to homeowner $i$ in the sample of total housing services. The sum is across homeowners because renters do not contribute to the bias as their services are appropriately valued.

\subsubsection{An unweighted bias}

To gain some intuition on the determinants of this bias, we start by assuming that $\eta^{i}$ is equal for all households and equal to their weight in the total population, $1 / N$. This amounts to assuming that all households consume the same amount of housing services. The bias in (24) becomes:

$$
b^{u}=\frac{1}{N} \times \sum_{i \mid h^{i}>0} \frac{u c^{i}-r^{f}}{r^{f}}=\text { the homeownership rate } \times \frac{\overline{u c}-r^{f}}{r^{f}},
$$


Table 4

The unweighted bias in the cost of housing services

\begin{tabular}{|c|c|c|c|c|}
\hline & $\begin{array}{l}\text { Total } \\
\text { (1) }\end{array}$ & $\begin{array}{l}\text { No adj. costs } \\
\text { (2) }\end{array}$ & $\begin{array}{l}\text { No cap. gains } \\
\text { (3) }\end{array}$ & $\begin{array}{l}\text { No adj. cost nor } \\
\text { cap. gains } \\
\text { (4) }\end{array}$ \\
\hline Benchmark & $\begin{array}{r}-9.18 \\
(0.66)\end{array}$ & $\begin{array}{r}-14.03 \\
(0.67)\end{array}$ & $\begin{array}{r}-9.08 \\
(0.11)\end{array}$ & $\begin{array}{r}-13.93 \\
(0.06)\end{array}$ \\
\hline $\begin{array}{l}\text { Lower deduction } \\
\qquad\left(\tau_{m}=0.8\right)\end{array}$ & $\begin{array}{r}-7.77 \\
(0.66)\end{array}$ & $\begin{array}{r}-12.60 \\
(0.67)\end{array}$ & $\begin{array}{r}-7.67 \\
(0.10)\end{array}$ & $\begin{array}{r}-12.50 \\
(0.06)\end{array}$ \\
\hline $\begin{array}{l}\text { Lower tax } \\
\qquad\left(\tau_{y}=0.15\right)\end{array}$ & $\begin{array}{c}-5.54 \\
(0.66)\end{array}$ & $\begin{array}{r}-10.50 \\
(0.67)\end{array}$ & $\begin{array}{c}-5.49 \\
(0.10)\end{array}$ & $\begin{array}{r}-10.44 \\
(0.06)\end{array}$ \\
\hline $\begin{array}{l}\text { Higher tax } \\
\qquad\left(\tau_{y}=0.25\right)\end{array}$ & $\begin{array}{r}-12.75 \\
(0.66)\end{array}$ & $\begin{array}{r}-17.52 \\
(0.66)\end{array}$ & $\begin{array}{r}-12.66 \\
(0.10)\end{array}$ & $\begin{array}{r}-17.43 \\
(0.07)\end{array}$ \\
\hline $\begin{array}{l}\text { Higher cost } \\
\qquad(\chi=10 \%)\end{array}$ & $\begin{array}{r}-7.40 \\
(0.62)\end{array}$ & $\begin{array}{r}-13.97 \\
(0.63)\end{array}$ & $\begin{array}{c}-7.31 \\
(0.16)\end{array}$ & $\begin{array}{r}-13.88 \\
(0.07)\end{array}$ \\
\hline $\begin{array}{l}\text { Lower downpay. } \\
\qquad(\theta=10 \%)\end{array}$ & $\begin{array}{r}-9.92 \\
(0.64)\end{array}$ & $\begin{array}{r}-13.67 \\
(0.64)\end{array}$ & $\begin{array}{r}-9.82 \\
(0.09)\end{array}$ & $\begin{array}{r}-13.57 \\
(0.06)\end{array}$ \\
\hline Alternative mov. shock & $\begin{array}{c}-9.01 \\
(0.68)\end{array}$ & $\begin{array}{r}-14.08 \\
(0.68)\end{array}$ & $\begin{array}{c}-8.92 \\
(0.10)\end{array}$ & $\begin{array}{r}-14.00 \\
(0.06)\end{array}$ \\
\hline No moving shock & $\begin{array}{r}-10.92 \\
(0.65)\end{array}$ & $\begin{array}{r}-14.02 \\
(0.65)\end{array}$ & $\begin{array}{r}-10.80 \\
(0.11)\end{array}$ & $\begin{array}{r}-13.90 \\
(0.06)\end{array}$ \\
\hline $\begin{array}{l}\text { Lower interest } \\
\qquad\left(r^{d}=r^{m}=2.5 \%\right)\end{array}$ & $\begin{array}{r}-7.50 \\
(0.94)\end{array}$ & $\begin{array}{r}-14.02 \\
(0.93)\end{array}$ & $\begin{array}{r}-7.39 \\
(0.14)\end{array}$ & $\begin{array}{r}-13.90 \\
(0.08)\end{array}$ \\
\hline $\begin{array}{l}\text { Higher depreciation } \\
\qquad\left(\delta^{h}=3 \%\right)\end{array}$ & $\begin{array}{r}-10.77 \\
(0.48)\end{array}$ & $\begin{array}{r}-13.89 \\
(0.49)\end{array}$ & $\begin{array}{r}-10.70 \\
(0.08)\end{array}$ & $\begin{array}{r}-13.82 \\
(0.06)\end{array}$ \\
\hline $\begin{array}{l}\text { Spread } \\
\qquad\left(r^{m}=5 \%\right)\end{array}$ & $\begin{array}{c}-1.54 \\
(0.67)\end{array}$ & $\begin{array}{r}-6.38 \\
(0.69)\end{array}$ & $\begin{array}{c}-1.49 \\
(0.09)\end{array}$ & $\begin{array}{c}-6.33 \\
(0.05)\end{array}$ \\
\hline $\begin{array}{l}\text { Catastrophic shock } \\
\quad(p=1 \%)\end{array}$ & $\begin{array}{r}-9.24 \\
(0.69)\end{array}$ & $\begin{array}{r}-14.07 \\
(0.70)\end{array}$ & $\begin{array}{c}-9.15 \\
(0.10)\end{array}$ & $\begin{array}{r}-13.98 \\
(0.06)\end{array}$ \\
\hline Acc. bequests & $\begin{array}{c}-9.40 \\
(0.68)\end{array}$ & $\begin{array}{r}-14.47 \\
(0.69)\end{array}$ & $\begin{array}{c}-9.33 \\
(0.12)\end{array}$ & $\begin{array}{r}-14.39 \\
(0.06)\end{array}$ \\
\hline TAXSIM & $\begin{array}{r}-13.71 \\
(0.66)\end{array}$ & $\begin{array}{r}-18.08 \\
(0.65)\end{array}$ & $\begin{array}{r}-13.61 \\
(0.09)\end{array}$ & $\begin{array}{r}-17.98 \\
(0.07)\end{array}$ \\
\hline
\end{tabular}

Notes. Standard deviation across 100 simulations in parentheses. The unweighted bias is calculated as $b^{u}=$ the homeownership rate $\times(\overline{u c}-$ $\left.r^{f}\right) / r^{f}$, where $\overline{u c}$ is the average user cost for homeowners and $r^{f}$ is the unit rental price of housing.

where $\overline{u c}$ is the average user cost across homeowners whose estimated value is shown in Table 3 . We call $b^{u}$ the "unweighted bias." Table 4 shows the value of $b^{u}$ for our different scenarios. In the case in which house prices do not vary over time and there are no buying costs, the unweighted bias simplifies to:

$$
b^{u}=-\tau_{y}+\frac{\left(1-\tau_{y}\right)\left(\overline{\mathcal{M}}\left(\hat{r}^{m}-\hat{r}^{d}\right)+\bar{\Gamma}\right)}{\hat{r}^{d}+\delta^{h}+\tau_{h}\left(1-\tau_{y}\right)} \times \text { the homeownership rate },
$$

where $\overline{\mathcal{M}}$ is the average loan-to-value ratio in the economy, and $\bar{\Gamma}$ is the mean transaction cost. The term $-\tau_{y}$ in expression (25) can be interpreted as the direct effect of preferential tax treatment on the user cost of housing. As long as owner-occupied housing services are not taxed and rental services are, this term is negative. The second term, which under our assumptions is nonnegative, becomes smaller with preferential tax treatment. In our simulations, the first term outweighs the second, resulting in a negative bias. For instance, in the benchmark case, ignoring adjustment costs and capital gains the bias will be equal to the income tax rate times the homeownership rate $(0.2 \times 0.71)$, which is -14 percent the number reported in Table 4 (column (4), first row). A negative bias means that when we use a rental equivalence approach to value housing services, we overestimate the value of housing. With adjustment costs, the unweighted bias is obviously lower, -9.2 percent in our benchmark scenario, because transaction costs increase the user cost.

Table 4 shows the unweighted bias for the different scenarios considered. In all cases the bias is negative, which means that a rental equivalence approach overestimates the cost of housing services for homeowners (we do not write the negative sign in front of the reported figures from now on). A lower tax deduction in mortgage payments, $\tau_{m}=0.8$, reduces the bias from 9.2 to 7.8 percent. This is because a lower deduction increases the after-tax mortgage 
cost, increasing the user cost, while the rental price remains unchanged. As a result, the bias decreases. A reduction in the income tax rate reduces the bias by almost four percentage points, from 9 percent in the benchmark case to 5.5 percent when $\tau_{y}=0.15$. This is because the lower the income tax, the lower the difference between the user cost and the rental price due to the fact that owner-occupied housing services are not taxed. The opposite occurs when the income tax rate increases (the bias rises from 9 to 12.75 percent when $\tau_{y}=0.25$ ).

A reduction in the interest rate, $r^{d}=r^{m}=2.5 \%$, lowers the unweighted bias from 9.2 to 7.5 percent. Ignoring adjustment costs, the unweighted bias is 14.03 percent in the benchmark calibration and 14.02 percent in the case with lower interest rates. Thus, the main source for the reduction in the bias in this case is the higher present value of the adjustment cost households bear if they sell their houses the next period. Higher depreciation results in a higher bias, 10.8 percent. A higher depreciation rate increases both the user cost and the rental price, but less so the user cost because of the preferential tax treatment on owner-occupied housing. With higher selling costs, $\chi=10 \%$, the bias goes down to 7.4 percent. Although households respond by selling their houses less often (the moving rate falls from 0.14 in the benchmark case to 0.11 ), still those who do move must pay a higher cost, resulting in a higher user cost and a lower bias. With a lower down payment, $\theta=10 \%$, the bias increases to 9.9 percent. In this case, households move less often since they can borrow more against the accumulated equity in their houses, weakening somewhat the effect of the adjustment cost. When we eliminate the moving shock, the unweighted bias becomes slightly larger, 10.9 percent, again because households pay adjustment costs less often. The introduction of spread, $r^{m}=5 \%$, drastically reduces the unweighted bias to 1.6 percent. This is because the rental price of housing is not affected when we introduce spread (as we have assumed that landlords do not borrow to buy their rental properties) but the mean user cost does. The introduction of a catastrophic shock (zero earnings) and the existence of accidental bequests do not affect the unweighted bias significantly. Finally, note in the row labeled 'TAXSIM' that the bias in this case is very similar to that found for a higher income tax rate. In the TAXSIM calibration the rate at which income from rental housing is taxed is higher, $\tau_{d}=0.292$, but its effect on the bias is partially offset by the fact that mortgage interest rates are not fully deductible. In summary, the unweighted bias is most sensitive to changes in the income tax rate, the spread between the after-tax interest rates on mortgages and deposits, and the level of adjustment costs.

\subsubsection{A properly weighted bias}

Since all homeowners are given equal weight, the changes in the unweighted bias just discussed operate through changes in the mean user cost of housing. The true bias, however, should take into account the fact that homeowners may differ in the amount of housing services they consume. The bias, after all, is the discrepancy in the value of aggregate housing services when we price owner-occupied housing services using the rental price instead of the user cost shown in Eq. (22). Thus, we calculate an appropriately weighted bias (simply referred to as 'the bias') as:

$$
b=\sum_{i \mid h^{i}>0} \frac{u c^{i}-r^{f}}{r^{f}} \frac{r^{f} h^{i}}{r^{f}(H+F)},
$$

where $r^{f}(H+F)$ is the value of aggregate housing services using the current rental equivalence approach ( $H$ is the owner-occupied housing stock while $F$ is the housing stock for rent). In turn, $r^{f} h^{i}$ is the value of the housing services-priced according to the rental price-consumed by homeowner $i$.

Table 5 shows the estimated bias for our benchmark economy and several alternative scenarios. In the benchmark case, the true value of housing services is 10.9 percent lower than the value calculated using the rental price. When adjustment costs are ignored, the bias increases to 16.5 percent. Ignoring capital gains does not have a significant effect as expected capital gains are calibrated to be zero. Note the bias, 10.9 percent, is higher than the unweighted bias, 9.2 percent. This is because homeowners, on average, consume more housing services than renters. While the homeownership rate is 71 percent, the fraction of housing services consumed by homeowners is 81 percent in the benchmark calibration (see Table 1). That is, the fraction of housing services acquired through ownership is larger than the homeownership rate.

As in the previous case, the bias is very sensitive to changes in the income tax rate: a reduction of $\tau_{y}$ to 15 percent reduces the bias from 10.9 percent to 6.5 , whereas with the higher rate, 25 percent, we obtain a much larger bias, 15.2 percent. In the TAXSIM calibration the bias is even higher, 16.8 percent. This is a direct result of owner-occupied housing services being untaxed and the tax rate being higher in this case. A lower deductability of mortgage interest payments, $\tau_{m}=0.8$, reduces the bias since holding mortgages becomes more costly. As with the unweighted bias, 
Table 5

The bias in the cost of housing services

\begin{tabular}{|c|c|c|c|c|c|}
\hline & \multirow{2}{*}{$\begin{array}{l}\text { Unweighted } \\
\text { (1) }\end{array}$} & \multicolumn{4}{|c|}{ Weighted by housing services } \\
\hline & & $\begin{array}{l}\text { Total } \\
\text { (2) }\end{array}$ & $\begin{array}{l}\text { No adj. costs } \\
\text { (3) }\end{array}$ & $\begin{array}{l}\text { No cap. gains } \\
\text { (4) }\end{array}$ & $\begin{array}{l}\text { No adj. cost nor } \\
\text { cap. gains } \\
\text { (5) }\end{array}$ \\
\hline Benchmark & $\begin{array}{r}-9.18 \\
(0.66)\end{array}$ & $\begin{array}{r}-10.86 \\
(1.03)\end{array}$ & $\begin{array}{r}-16.45 \\
(1.02)\end{array}$ & $\begin{array}{r}-10.65 \\
(0.15)\end{array}$ & $\begin{array}{r}-16.24 \\
(0.07)\end{array}$ \\
\hline $\begin{array}{l}\text { Lower deduction } \\
\qquad\left(\tau_{m}=0.8\right)\end{array}$ & $\begin{array}{r}-7.77 \\
(0.66)\end{array}$ & $\begin{array}{r}-9.23 \\
(1.00)\end{array}$ & $\begin{array}{r}-14.77 \\
(1.01)\end{array}$ & $\begin{array}{r}-9.04 \\
(0.15)\end{array}$ & $\begin{array}{r}-14.58 \\
(0.06)\end{array}$ \\
\hline $\begin{array}{l}\text { Lower tax } \\
\qquad\left(\tau_{y}=0.15\right)\end{array}$ & $\begin{array}{c}-5.54 \\
(0.66)\end{array}$ & $\begin{array}{r}-6.54 \\
(0.99)\end{array}$ & $\begin{array}{r}-12.08 \\
(1.02)\end{array}$ & $\begin{array}{r}-6.40 \\
(0.16)\end{array}$ & $\begin{array}{r}-11.93 \\
(0.06)\end{array}$ \\
\hline $\begin{array}{l}\text { Higher tax } \\
\qquad\left(\tau_{y}=0.25\right)\end{array}$ & $\begin{array}{r}-12.75 \\
(0.66)\end{array}$ & $\begin{array}{r}-15.19 \\
(1.10)\end{array}$ & $\begin{array}{r}-20.89 \\
(1.11)\end{array}$ & $\begin{array}{r}-15.02 \\
(0.15)\end{array}$ & $\begin{array}{r}-20.72 \\
(0.07)\end{array}$ \\
\hline $\begin{array}{l}\text { Higher cost } \\
\qquad(\chi=10 \%)\end{array}$ & $\begin{array}{r}-7.40 \\
(0.62)\end{array}$ & $\begin{array}{r}-8.57 \\
(0.98)\end{array}$ & $\begin{array}{r}-16.20 \\
(1.00)\end{array}$ & $\begin{array}{r}-8.37 \\
(0.25)\end{array}$ & $\begin{array}{r}-16.00 \\
(0.07)\end{array}$ \\
\hline $\begin{array}{l}\text { Lower downpay. } \\
\qquad(\theta=10 \%)\end{array}$ & $\begin{array}{r}-9.92 \\
(0.64)\end{array}$ & $\begin{array}{r}-11.75 \\
(1.06)\end{array}$ & $\begin{array}{r}-16.13 \\
(1.06)\end{array}$ & $\begin{array}{r}-11.54 \\
(0.12)\end{array}$ & $\begin{array}{r}-15.92 \\
(0.06)\end{array}$ \\
\hline Alternative mov. shock & $\begin{array}{c}-9.01 \\
(0.68)\end{array}$ & $\begin{array}{r}-10.50 \\
(1.01)\end{array}$ & $\begin{array}{r}-16.24 \\
(1.01)\end{array}$ & $\begin{array}{r}-10.33 \\
(0.14)\end{array}$ & $\begin{array}{r}-16.06 \\
(0.06)\end{array}$ \\
\hline No moving shock & $\begin{array}{r}-10.92 \\
(0.65)\end{array}$ & $\begin{array}{r}-12.82 \\
(1.00)\end{array}$ & $\begin{array}{r}-16.55 \\
(1.00)\end{array}$ & $\begin{array}{r}-12.61 \\
(0.18)\end{array}$ & $\begin{array}{r}-16.35 \\
(0.06)\end{array}$ \\
\hline $\begin{array}{l}\text { Lower interest } \\
\qquad\left(r^{d}=r^{m}=2.5 \%\right)\end{array}$ & $\begin{array}{r}-7.50 \\
(0.94)\end{array}$ & $\begin{array}{r}-8.79 \\
(1.35)\end{array}$ & $\begin{array}{r}-16.10 \\
(1.36)\end{array}$ & $\begin{array}{r}-8.50 \\
(0.20)\end{array}$ & $\begin{array}{r}-15.80 \\
(0.08)\end{array}$ \\
\hline $\begin{array}{l}\text { Higher depreciation } \\
\qquad\left(\delta^{h}=3 \%\right)\end{array}$ & $\begin{array}{r}-10.77 \\
(0.48)\end{array}$ & $\begin{array}{r}-12.79 \\
(0.79)\end{array}$ & $\begin{array}{r}-16.53 \\
(0.80)\end{array}$ & $\begin{array}{r}-12.65 \\
(0.12)\end{array}$ & $\begin{array}{r}-16.40 \\
(0.07)\end{array}$ \\
\hline $\begin{array}{l}\text { Spread } \\
\qquad\left(r^{m}=5 \%\right)\end{array}$ & $\begin{array}{r}-1.54 \\
(0.67)\end{array}$ & $\begin{array}{c}-2.01 \\
(0.98)\end{array}$ & $\begin{array}{c}-7.47 \\
(1.02)\end{array}$ & $\begin{array}{c}-1.86 \\
(0.16)\end{array}$ & $\begin{array}{c}-7.32 \\
(0.07)\end{array}$ \\
\hline $\begin{array}{l}\text { Catastrophic shock } \\
\quad(p=1 \%)\end{array}$ & $\begin{array}{r}-9.24 \\
(0.69)\end{array}$ & $\begin{array}{r}-10.93 \\
(1.03)\end{array}$ & $\begin{array}{r}-16.51 \\
(1.06)\end{array}$ & $\begin{array}{r}-10.75 \\
(0.15)\end{array}$ & $\begin{array}{r}-16.33 \\
(0.07)\end{array}$ \\
\hline Acc. bequests & $\begin{array}{r}-9.40 \\
(0.68)\end{array}$ & $\begin{array}{r}-10.60 \\
(0.97)\end{array}$ & $\begin{array}{r}-16.39 \\
(0.98)\end{array}$ & $\begin{array}{r}-10.46 \\
(0.16)\end{array}$ & $\begin{array}{r}-16.25 \\
(0.06)\end{array}$ \\
\hline TAXSIM & $\begin{array}{r}-13.71 \\
(0.66)\end{array}$ & $\begin{array}{r}-16.77 \\
(1.13)\end{array}$ & $\begin{array}{r}-22.02 \\
(1.14)\end{array}$ & $\begin{array}{r}-16.55 \\
(0.15)\end{array}$ & $\begin{array}{r}-21.80 \\
(0.07)\end{array}$ \\
\hline
\end{tabular}

Notes. Standard deviation across 100 simulations in parentheses. The bias is calculated as $b=\sum_{i \mid h^{i}>0}\left(u c^{i}-r^{f}\right) / r^{f} \times \eta_{i}$, where $u c^{i}$ is the user cost for homeowner $i, r^{f}$ is the unit rental price, and $\eta_{i}$ measures the amount of housing services consumed by household $i$ relative to all housing services in the economy.

the lowest bias is obtained in the scenario where we introduce spread, 2 percent. The figures for all other scenarios in Table 5 illustrate that the bias also changes with interest rates, with changes in the adjustment costs and in the down payment. The reasons have been already outlined when discussing the determinants of the unweighted bias. The main difference is that, in all the scenarios considered, the (weighted) bias is larger than the unweighted bias because the fraction of housing services acquired through ownership is larger than the homeownership rate.

One question that arises is how reliable our estimate of the bias is. If we ignore capital gains and adjustment costs, the bias in our benchmark economy is simply equal to the mean user cost in (23) times the fraction of services acquired through homeownership, $r^{f} H /\left(r^{f} H+r^{f} F\right)$. In our benchmark calibration this fraction is 81 percent (see Table 1). In NIPA, the ratio of owner-occupied housing services to total housing services is about 79 percent for 2005 (but the ratio has been increasing over time starting from a value of 67 percent in 1955). In Table 7, we report that the median house value for homeowners divided by the sum of the median house value plus the median rent is roughly 95 percent in the Survey of Consumer Finances. We calculate the ratio $q H /\left(q H+r^{f} F\right)$ in our model, which is 97 percent in our benchmark calibration and does not change much across scenarios (see Table 1). Thus, the distribution of housing services between renters and homeowners in our model is similar to the distribution in the data. An additional concern is the fact that the life-cycle profile for homeownership in our model does not exactly match the one in the data. In Fig. 2, panel (b), we show that we overestimate homeownership for older cohorts and underestimate it for the younger ones. In other words, our measure of the bias gives a higher weight to cohorts with more housing but a lower user cost since the user cost decreases with age as shown in Fig. 3, panel (b). If in reality the user cost for younger cohorts in 
systematically higher than for older cohorts and we give a higher weight to the user cost of older cohorts because we overestimate their consumption of owner-occupied housing services, our bias could be inflated somewhat. However, the fact that homeownership among the young (old) is higher (lower) in reality may indicate that their user cost relative to the rental price is lower (higher) than in our model so it is difficult to determine if our bias is indeed biased. In any case, the unweighted bias, which weights all homeowners equally, does not have this problem and can be seen as a lower bound.

To summarize, the bias we find in our benchmark case, -10.9 percent, tells us that the cost of owner-occupied housing services is overvalued when calculated using a rental equivalence approach. The main reason is that owneroccupied housing services are not taxed. To reiterate, assume these services were taxed, house prices were constant and abstract from buying costs. Then, the unweighted bias simplifies to:

$$
b^{u}=\frac{\overline{\mathcal{M}}\left(\hat{r}^{m}-\hat{r}^{d}\right)+\bar{\Gamma}}{\hat{r}^{d}+\delta^{h}+\hat{\tau}_{h}} \times \text { the homeownership rate, }
$$

which is nonnegative as long as $\hat{r}^{m} \geqslant \hat{r}^{d}$. A positive bias means that the user cost, on average, is higher than the rental price. Recall that we have calculated the user cost as the realized cost of housing, which does not need to be the same as the ex ante cost households use when deciding on tenure choice. It can be the case that the realized user cost is higher than the rental price and, still, households may prefer owning to renting, as we need to take into account that owning a house gives access to collateralized credit and isolates a fraction of total consumption against idiosyncratic shocks.

\section{Concluding remarks}

In this paper, we build a partial equilibrium life-cycle model with endogenous tenure choice that we use to quantify possible biases when using a rental equivalence approach to compute the cost of housing for both renters and homeowners. Our model includes idiosyncratic earnings uncertainty, house price risk, down payments, transactions costs and tax advantages from homeownership. These tax advantages, particularly the fact that owner-occupied housing services are not taxed, substantially affect the bias. In our benchmark scenario, the bias resulting from pricing services of owner-occupied housing (for which there is no market) using the rental price is about -10.9 percent. That is, a rental equivalence approach overestimates the value of housing services substantially. Importantly, we show that the income tax rate is the most important determinant of the bias. We believe that our findings are informative for the debate on how to accurately measure the housing component of the cost of living.

For computational reasons, the model has been simplified along several dimensions that should be addressed in future research. For example, the normalization needed to solve the household problem prevents us from analyzing the case of a progressive tax system. We have also abstracted from risk on financial assets. Perhaps most importantly, we have assumed a particular process for the rental price of housing, which is reasonable, but ignores potentially important issues such as moral hazard (see Henderson and Ioannides, 1983). More work is needed to understand the dynamics of user cost and rents.

\section{Acknowledgments}

The authors thank the Dirección General de Universidades e Investigación de la Comunidad de Madrid, project 06/HSE/0159/2004, for financial support. They are also grateful to participants of the 2005 MEA workshop at Mannheim University, as well as seminar participants at the BLS (particularly Randal Verbrugge), the Brookings Institution, University of Connecticut, Universidad del País Vasco, Universidad de Barcelona and FEDEA. Antonia Díaz thanks FEDEA for its hospitality while working on this project.

\section{Appendix A. The household portfolio}

If we solve the household's problem shown in Section 2.5 we obtain the following first order conditions,

$$
\begin{aligned}
& c_{t}: \beta^{t} \zeta^{t} u_{c}\left(c_{t}, x_{t} f_{t}+\left(1-x_{t}\right) h_{t}\right)-\lambda_{t}=0, \quad \text { for all } t \leqslant T ; \\
& c_{t}:-\lambda_{t}=0, \quad \text { for all } t \geqslant T ;
\end{aligned}
$$




$$
\begin{aligned}
& d_{t}:-\lambda_{t}+E_{t}\left\{\lambda_{t+1}\left(1+\hat{r}_{t+1}^{d}\right)\right\}+\varphi_{t}^{d}=0, \quad \text { for all } t \leqslant T ; \\
& m_{t}: \lambda_{t}-E_{t}\left\{\lambda_{t+1}\left(1+\hat{r}_{t+1}^{m}\right)\right\}+\varphi_{t}^{m}-\mu_{t}=0, \quad \text { for all } t \leqslant T ;
\end{aligned}
$$

where $\lambda_{t}$ is the multiplier of the budget constraint, $\varphi_{t}^{d}$ and $\varphi_{t}^{m}$ are the multipliers of the nonnegativity constraints for deposits and mortgages, respectively, and $\mu_{t}$ is the multiplier associated to the borrowing constraint shown in (2).

Lemma 1. The borrowing constraint and the nonnegativity constraints on mortgages cannot bind simultaneously.

\section{A.1. No spread and full deductability}

Lemma 2. The nonnegativity constraint on deposits and mortgages cannot bind simultaneously.

Proof. We prove it by contradiction. Let us assume that $\varphi_{t}^{d}>0$ and $\varphi_{t}^{m}>0$. If $\varphi_{t}^{d}>0$, then by (31) we have that $-\lambda_{t}+E_{t}\left\{\lambda_{t+1}\left[1+\hat{r}_{t+1}^{d}\right]\right\}<0$. In (32), this implies that $\mu_{t}>0$, violating Lemma 1 . Therefore, the two nonnegativity constraints cannot bind at the same time.

Lemma 3. The nonnegativity constraint on mortgages is never binding, $\varphi_{t}^{m}=0$.

Proof. If $\varphi_{t}^{d}>0$ then Lemma 2 ensures that $\varphi_{t}^{m}=0$. If $\varphi_{t}^{d}=0$, then we have that $\varphi_{t}^{m}=\mu_{t}$. If $\varphi_{t}^{m}>0$ this implies that $\mu_{t}>0$, which contradicts Lemma 1 .

Proposition 1. Assume that there is no spread between the return on deposits and the mortgage rate, and that mortgage interest payments are fully deductible (i.e., $r_{t}^{d}=r_{t}^{m} \forall t$, and $\tau_{m}=1$ ). Then, households in their last period life hold no deposits. All other households can be divided in two groups. Those who are liquidity constrained hold no deposits. Those who are not liquidity constrained are only concerned with their net position $d_{t}-m_{t}, \forall t<T$.

Proof. Adding expressions (31) and (32) we obtain $\varphi_{t}^{d}+\varphi_{t}^{m}-\mu_{t}=0$. By Lemma 3 this expression becomes $\varphi_{t}^{d}=\mu_{t}$. Thus, if the borrowing constraint is binding the household holds no deposits and $m_{t}=(1-\theta) q_{t} h_{t}$. If the borrowing constraint is not binding only the difference $d_{t}-m_{t}$ matters.

\section{A.2. Spread or partial deductability}

Proposition 2. Assume that there is spread between the return on deposits and the mortgage rate or that mortgage interest payments are not fully deductible (i.e., $r_{t}^{d}<r_{t}^{m}$ or $\tau_{m}<1$ ). Then, households do not simultaneously hold deposits and debt. In particular, households in the last period of life hold no deposits.

Proof. Adding expressions (31) and (32) we obtain:

$$
E_{t} \lambda_{t+1}\left[\hat{r}_{t+1}^{d}-\hat{r}_{t+1}^{m}\right]+\varphi_{t}^{d}+\varphi_{t}^{m}-\mu_{t}=0
$$

Since the expression inside the brackets is negative then $\varphi_{t}^{d}+\varphi_{t}^{m}-\mu_{t}>0$, which implies that $\varphi_{t}^{d}+\varphi_{t}^{m}>0$. Thus, households do not hold simultaneously positive amounts of deposits and debt. Specifically, borrowing constrained households do not hold deposits.

\section{Appendix B. The data}

We use data from the Survey of Consumer Finances conducted by the Federal Reserve Board. Our definition of earnings is taken from Budria et al. (2002). According to their definition, some households in the sample have negative earnings (business owners with severe losses). Since our model cannot account for this case, we have restricted our sample to those households with nonnegative earnings. Moreover, since in our model households' net worth cannot be negative, we have further restricted our sample to those households with nonnegative wealth. The definition of household's net worth is the one used in the SCF: total assets minus total liabilities. The variable housing comprises the items called primary and secondary residence in the SCF and its value is gross of any collateralized debt. That is, 
Table 6

Data from the survey of consumer finances I

\begin{tabular}{|c|c|c|c|c|c|c|}
\hline Year & 1989 & 1992 & 1995 & 1998 & 2001 & 2004 \\
\hline \multicolumn{7}{|c|}{ Total population } \\
\hline Mean earnings ${ }^{\mathrm{a}}$ & 38,595 & 39,803 & 41,234 & 46,164 & 53,135 & 48,717 \\
\hline Median $E$ & 0.66 & 0.64 & 0.66 & 0.67 & 0.62 & 0.64 \\
\hline Median $q H$ & 1.52 & 1.45 & 1.63 & 1.68 & 1.56 & 2.25 \\
\hline Median W & 1.89 & 1.68 & 1.77 & 1.95 & 1.87 & 2.10 \\
\hline Median $q H / W$ & 0.82 & 0.86 & 0.84 & 0.79 & 0.76 & 0.89 \\
\hline Homeow. rate $(\%)$ & 70.14 & 69.97 & 70.99 & 72.07 & 72.67 & 74.93 \\
\hline \multicolumn{7}{|c|}{ Working-age population } \\
\hline Population (\%) & 78.74 & 78.54 & 78.36 & 78.41 & 78.85 & 78.94 \\
\hline Median $E$ & 0.92 & 0.87 & 0.87 & 0.88 & 0.79 & 0.84 \\
\hline Median $q H$ & 1.55 & 1.45 & 1.58 & 1.68 & 1.53 & 2.25 \\
\hline Median $W$ & 1.68 & 1.45 & 1.52 & 1.63 & 1.58 & 1.75 \\
\hline Median $q H / W$ & 0.91 & 0.92 & 0.92 & 0.86 & 0.81 & 0.98 \\
\hline$W / E$ & 1.80 & 1.57 & 1.64 & 1.81 & 1.88 & 2.10 \\
\hline Homeow. rate $(\%)$ & 68.21 & 67.22 & 68.65 & 69.55 & 70.36 & 72.10 \\
\hline \multicolumn{7}{|c|}{ Population over 66} \\
\hline Population (\%) & 21.26 & 21.46 & 21.64 & 21.59 & 21.15 & 21.06 \\
\hline Median $q H$ & 1.48 & 1.69 & 1.79 & 1.80 & 1.78 & 2.33 \\
\hline Median $W$ & 2.69 & 2.74 & 2.67 & 3.12 & 3.09 & 3.42 \\
\hline Median $q H / W$ & 0.62 & 0.69 & 0.67 & 0.65 & 0.63 & 0.69 \\
\hline Homeow. rate $(\%)$ & 77.28 & 80.04 & 79.43 & 81.23 & 81.27 & 85.53 \\
\hline
\end{tabular}

Notes. $E$ denotes earnings, $W$ denotes wealth, and $q H$ denotes house value. Median earnings, house values and wealth are divided by mean earnings in the sample. The median house to wealth ratio, $q H / W$, refers to the subsample of homeowners.

a Mean earnings in 2000 dollars.

the value of housing $q H$ is the full value of the house, not home equity. Households that report no housing stock are assumed to be renters.

Table 6 shows selected statistics from six waves of the SCF. Several things are worth noting. First, the population composition between working-age households and households whose head is 66 or older is very stable over time. The homeownership rate increases steadily over time for both groups. There is no significant trend in the median value of earnings, house value or net worth (relative to the mean value of earnings for the total population within the period considered). This is true for the entire population as well as the two subgroups. The median wealth-to-earnings ratio for working-age households does not show a significant trend either. This is also the case for our measure of portfolio composition, the median ratio of house value to total wealth. In Figs. 4 and 5, we show the evolution of several statistics. Fig. 4 (first row, right panel) shows the mean (across waves of the SCF) of median earnings for each cohort (the thick line). This is not a life-cycle profile of median earnings, but the distribution of median earnings across cohorts. The vertical lines in the plot show, respectively, the maximum and the minimum value of median earnings for a given age cohort across the SCF waves. Note the differences across SCF waves are not too large. This implies that the distribution of earnings across cohorts in a given SCF wave may not be a bad approximation of the true life-cycle profile of earnings for the median household. This is also the case for the rest of the statistics considered. For most cohorts the value of houses and wealth in 2004 is much larger than in previous years. Note, though, that the median house value to total wealth ratio for homeowners, shown in Fig. 5, does not change significantly over time-the peak in the maximum value of this statistic for the 60-63 cohort corresponds to the 2004 wave, a period of considerable housing price appreciation.

In Table 7, we report statistics for households classified according to their level of education. We can see that the fraction of households with at least some college is increasing over time. The median household is a households with a high school diploma in the initial years and, in later years, a household with some years of college. Also, workers with at least some college have a higher wealth-to-earnings ratio, a lower housing value to wealth ratio and higher homeownership rates. The main difference across waves of the SCF is that the homeownership rate for high schoolers and households with some college is increasing over time. Finally, the SCF contains information on rental payments for renters (at different periodicities depending on the specific household), but not on the rental price. We calculate annual-equivalent rental payments for all renters. In our notation, aggregate annual rental payments are equal to $r^{f} F$, 

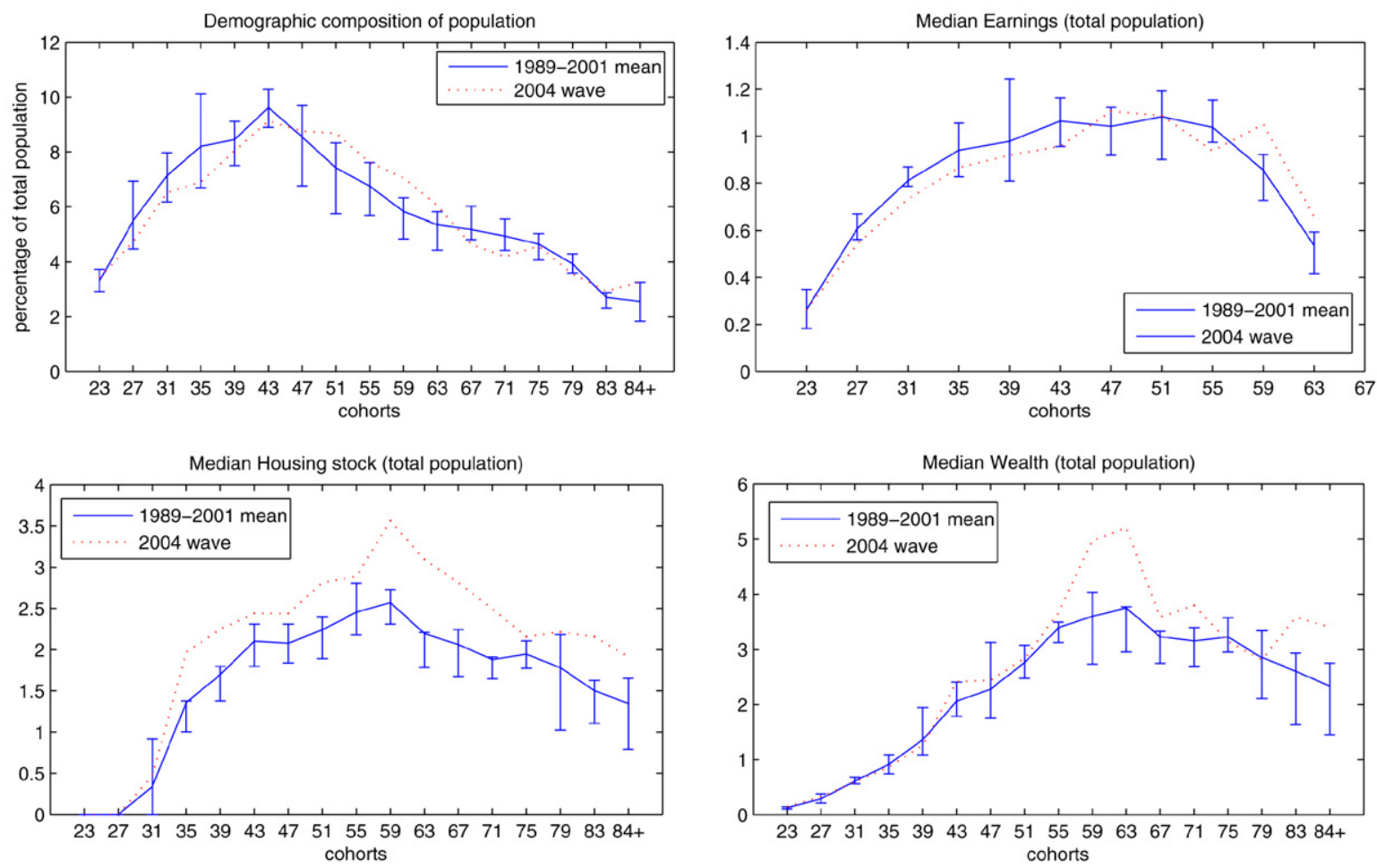

Fig. 4. Data from the SCF I.
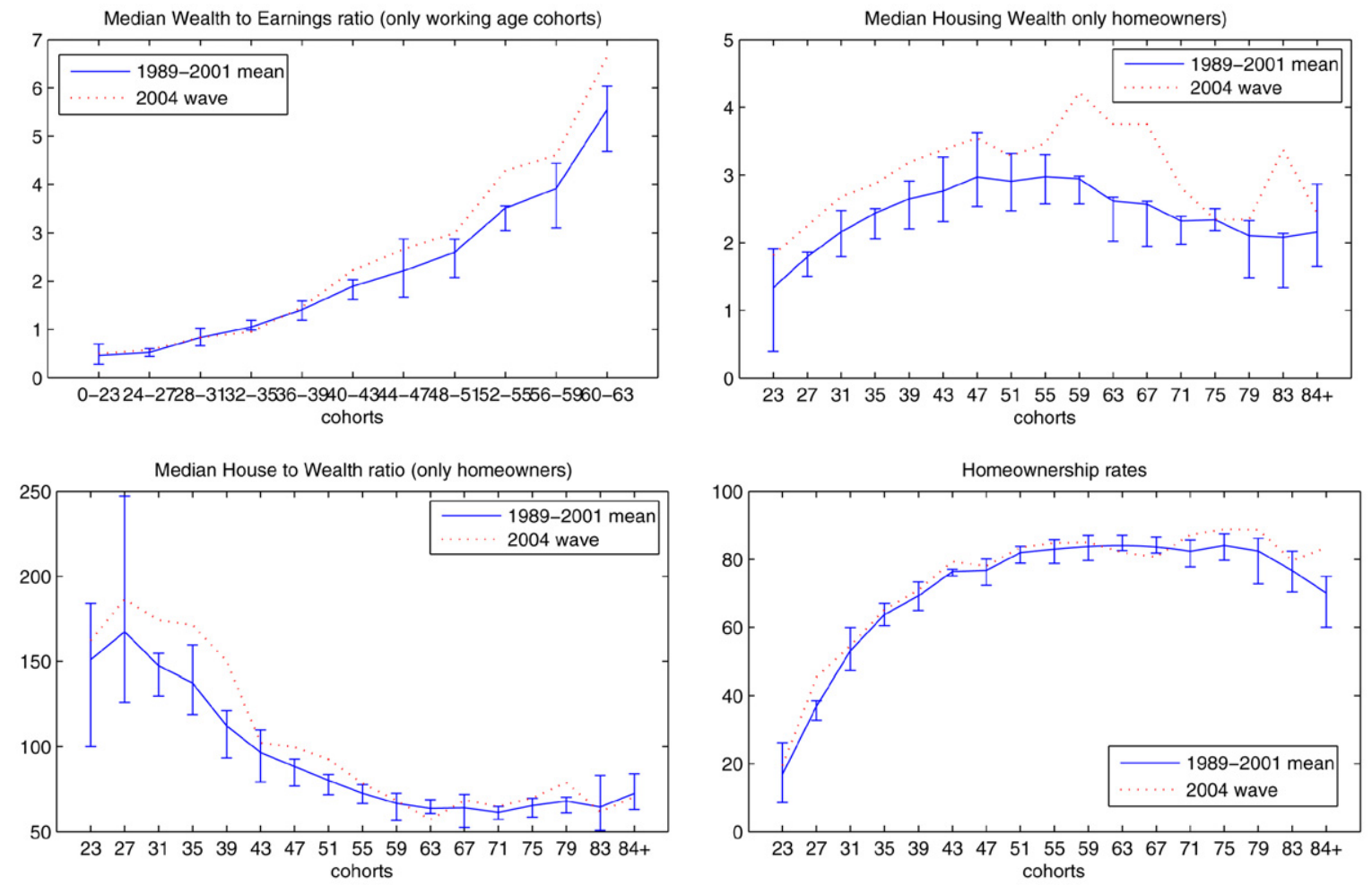

Fig. 5. Data from the SCF II. 
Table 7

Data from the survey of consumer finances II

\begin{tabular}{|c|c|c|c|c|c|c|c|}
\hline Year & 1989 & 1992 & 1995 & 1998 & 2001 & 2004 & Mean \\
\hline \multicolumn{8}{|c|}{ Fraction of the total population } \\
\hline High school dropouts & 24.25 & 20.48 & 18.43 & 16.47 & 15.76 & 14.60 & 18.33 \\
\hline High school diploma & 31.92 & 29.84 & 31.93 & 32.42 & 31.83 & 31.27 & 31.53 \\
\hline Some college & 43.83 & 49.68 & 49.65 & 51.10 & 52.41 & 54.13 & 50.13 \\
\hline \multicolumn{8}{|c|}{ Median $W / E$ for working-age households } \\
\hline Total & 1.80 & 1.57 & 1.64 & 1.81 & 1.88 & 2.10 & 1.80 \\
\hline High school dropouts & 1.69 & 0.94 & 1.20 & 1.01 & 0.74 & 0.75 & 1.05 \\
\hline High school diploma & 1.34 & 1.20 & 1.48 & 1.33 & 1.37 & 1.52 & 1.37 \\
\hline Some college & 2.14 & 1.93 & 1.84 & 2.23 & 2.47 & 2.73 & 2.22 \\
\hline \multicolumn{8}{|c|}{ Homeownership rate $(\%)$} \\
\hline Total & 70.14 & 69.97 & 70.99 & 72.07 & 72.67 & 74.93 & 71.49 \\
\hline High school dropouts & 66.19 & 61.74 & 64.64 & 58.95 & 62.38 & 60.25 & 62.36 \\
\hline High school diploma & 66.34 & 68.11 & 71.15 & 71.13 & 69.58 & 70.57 & 69.48 \\
\hline Some college & 75.09 & 74.49 & 73.24 & 76.90 & 77.63 & 81.41 & 76.46 \\
\hline \multicolumn{8}{|c|}{ Median $q H / W$ for homeowners (\%) } \\
\hline Total & 81.97 & 85.59 & 83.61 & 78.97 & 75.76 & 88.51 & 82.40 \\
\hline High school dropouts & 86.32 & 86.31 & 88.84 & 84.89 & 83.49 & 94.54 & 87.40 \\
\hline High school diploma & 82.98 & 86.21 & 83.46 & 81.14 & 81.94 & 90.37 & 84.35 \\
\hline Some college & 78.57 & 84.52 & 81.21 & 75.74 & 67.43 & 84.09 & 78.59 \\
\hline \multicolumn{8}{|c|}{ Ratio of medians $q H /\left(q H+r^{f} F\right)(\%)$} \\
\hline Total & 95.71 & 95.29 & 95.11 & 95.32 & 95.51 & 96.49 & 95.57 \\
\hline High school dropouts & 94.34 & 93.75 & 94.70 & 94.58 & 94.98 & 94.20 & 94.43 \\
\hline High school diploma & 94.60 & 94.18 & 94.88 & 94.77 & 94.61 & 95.51 & 94.76 \\
\hline Some college & 96.32 & 95.82 & 95.60 & 95.73 & 95.94 & 96.76 & 96.03 \\
\hline
\end{tabular}

Notes. $W$ denotes wealth, $E$ denotes earnings. $q H$ denotes house value for homeowners. $r^{f} F$ denotes total rent for renters. The last ratio is the ratio of median house value to the sum of median house value plus median rent.

where $r^{f}$ is the rental price of housing and $F$ is the total amount of housing services purchased in the market. The last panel of Table 7 shows the ratio of the median house value $q H^{m}$ to the sum $q H^{m}+r^{f} F^{m}$, where $r^{f} F^{m}$ is the median rental payment. This ratio is about 95 percent for the various population groups considered.

\section{Appendix C. Alternative calibration using TAXSIM}

In reality, the various components of income (wages, interest income, dividends and capital gains) are effectively taxed at different rates. In this alternative calibration, we allow for different rates on labor and capital income. In principle, we could have used the effective tax rates calculated by Mendoza et al. (1997) or McGrattan and Prescott (2005) but we decided not to do so because these authors do not provide information on mortgage deductions. Since TAXSIM reports the effective deduction on mortgages, we prefer to use its estimates.

A table entitled "US Federal and State Average Marginal Income Tax Rates" in the NBER TAXSIM model reports that tax rates vary significantly by income source (we plot this information in Fig. 6). Even within the capital income category, interest income, dividends, short-term and long-term capital gains are taxed at very different rates. Since in our model we only have one source of capital income, we use a weighted average of the tax rates for these items. To construct appropriate weights, we calculate the share of interest income (net of the value of owner-occupied housing services), dividends and capital gains in the sum of those three items in Personal Income, as reported in Table 2.1 in NIPA (these shares are plotted in Fig. 7). Since we do not have information in NIPA about long-term and shortterm capital gains but the sum of both, we give them equal weight. The resulting average effective tax rate on capital income for the period 1996-2006 is $\tau_{d}=29.22$. The average effective tax rate on labor for the same period is $\tau_{w}=$ 27.54 percent. TAXSIM also reports an effective deduction rate of mortgages payments, which is $\tau_{m}=81.80$ percent (assuming the mortgage deduction applies at the higher labor income rate). These numbers implied an after-tax return on deposits, $\hat{r}^{d}=\left(1-\tau_{d}\right) r^{d}$, of 2.83 percent, and after-tax interest rate on mortgages, including the deduction, $\hat{r}^{m}=\left(1-\tau_{w} \tau_{m}\right) r^{m}$, of 3.1 percent. 

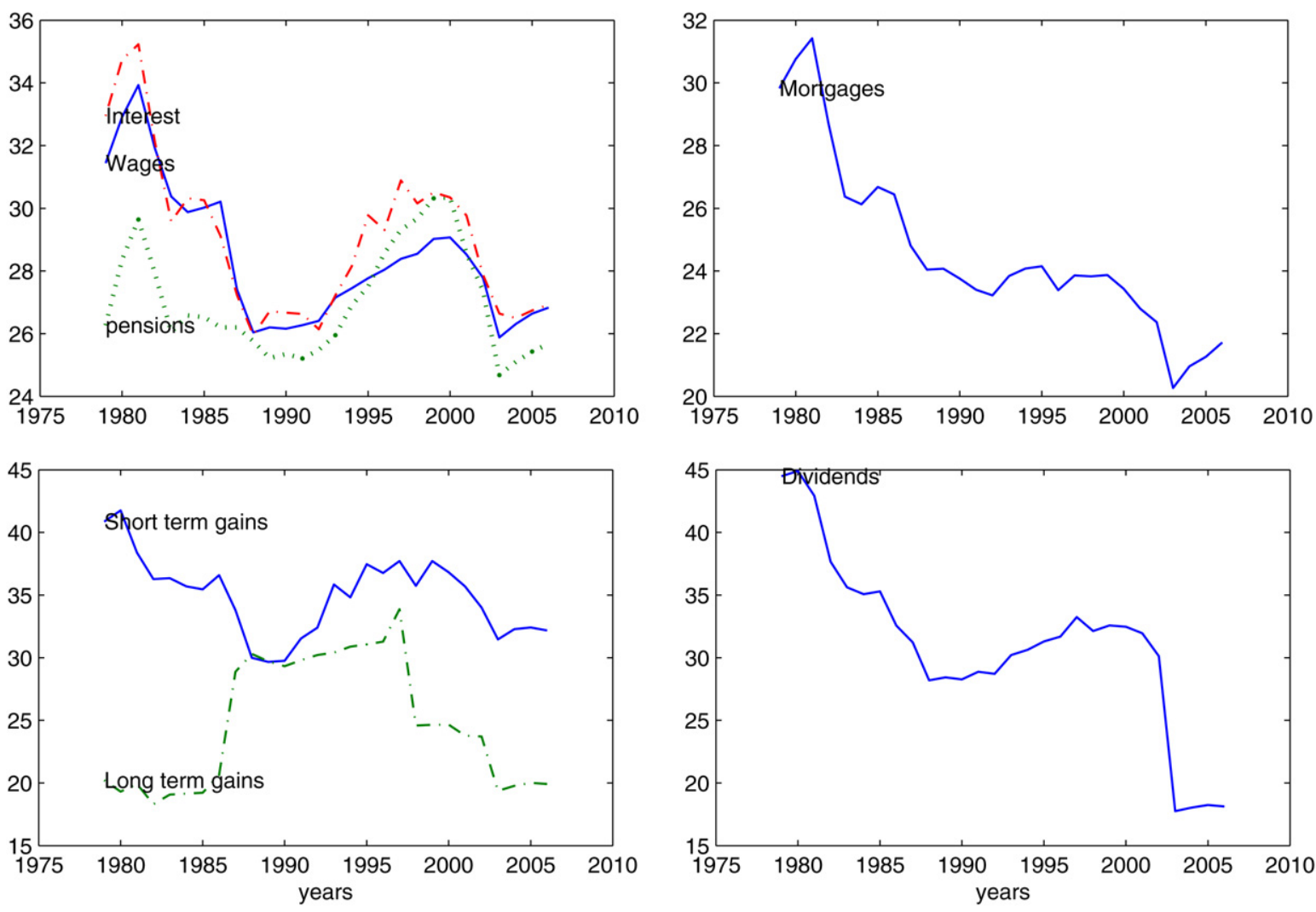

Fig. 6. Effective marginal tax rates from TAXSIM.

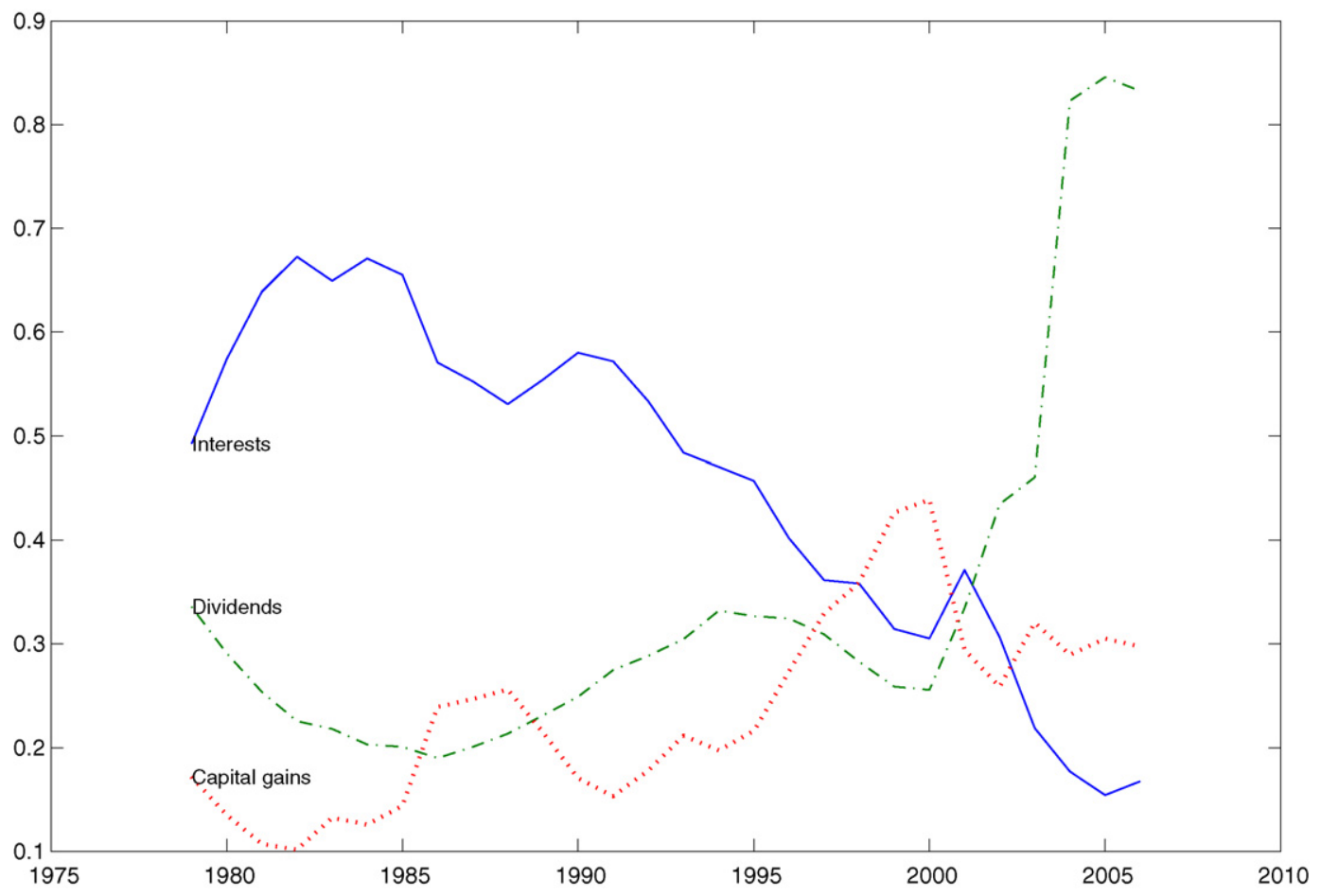

Fig. 7. Shares in total capital income from NIPA. 


\section{Appendix D. Solution method and simulation strategy}

In this appendix, we briefly describe our computational procedure and simulation strategy.

\section{D.1. Rewriting the model}

In our setup, deposits and mortgages can be lumped into a single asset, $a_{t}=d_{t}-m_{t}$. As seen in Section 2.6, with no spread and full deductability, household's are only concerned with their net financial position, $a_{t}$. With spread and/or partial deductability, households do not hold debt and deposits simultaneously since $\hat{r}_{t}^{m}>\hat{r}_{t}^{d}$ and it is costless to borrow against accumulated housing equity above the down payment. This simplification facilitates the computation of the model substantially since we do not need to keep track of deposits and mortgages separately. For a homeowner, $a_{t}>0$ indicates that the household has finished paying the house, while $a_{t}<0$ means the household still holds a mortgage. Additionally, we use $q_{t} h_{t}$, the house value, as a state variable instead of keeping track of house size and house prices separately. Our assumptions about the dynamics of housing price shocks and the rental price allow us to do this. We go one step further and define voluntary equity, $e_{t}$, the equity held in excess of the required down payment. That is,

$$
e_{t}=d_{t}-m_{t}+q_{t} h_{t}-\theta q_{t} h_{t}=a_{t}+(1-\theta) q_{t} h_{t} .
$$

Since our collateralized debt-constraint implies that wealth cannot be below the required down payment, $e_{t} \geqslant 0$. Finally, as proposed by Carroll (1997), we normalized the problem by permanent income. Thus, we solve the household problem using normalized voluntary equity and the normalized house value as the key state variables. It is easy to go back and forth from voluntary equity to net financial assets using Eq. (33). With this in mind, the budget constraint for the normalized problem can be written as:

$$
\begin{aligned}
\tilde{c}_{t} & +\tilde{r}_{t}^{f} \tilde{f}_{t}+\tilde{a}_{t}+\left(1+\tilde{\Psi}\left(\tilde{h}_{t}, \tilde{h}_{t-1}, z_{t}\right)\right) \tilde{h}_{t}+\tilde{\Gamma}\left(\tilde{h}_{t}, \tilde{h}_{t-1}, z_{t}\right) \frac{1+\varrho_{t}}{\gamma_{t} \epsilon_{t}}\left(1-\delta^{h}\right) \tilde{h}_{t-1} \\
& \leqslant v_{t}+\frac{1}{\gamma_{t} \epsilon_{t}}\left(\left(1+\hat{r}_{t}^{d}\right) \max \left(\tilde{a}_{t-1}, 0\right)+\left(1+\hat{r}_{t}^{m}\right) \min \left(\tilde{a}_{t-1}, 0\right)+\left(1+\varrho_{t}\right)\left(1-\delta_{h}-\tau_{h}\right) \tilde{h}_{t-1}\right) .
\end{aligned}
$$

$\tilde{c}=c_{t} / P_{t}$ and $\tilde{a}_{t}=a_{t} / P_{t}$ are consumption and net financial assets normalized by permanent income. $\tilde{f}_{t}=q_{t} f_{t} / P_{t}$ and $\tilde{h}_{t}=q_{t} h_{t} / P_{t}$ denote the value of housing services (rented and owned) normalized by permanent income, and $\tilde{r}_{t}^{f}=r_{t}^{f} / q_{t}$ is the rental price normalized by housing stock prices. $\gamma_{t}$ is the non-stochastic life-cycle component of earnings, and $\epsilon_{t}$ is the permanent stochastic component.

The buying cost function can be rewritten as:

$$
\tilde{\Psi}\left(\tilde{h}_{t}, \tilde{h}_{t-1}, z_{t}\right)= \begin{cases}0, & \text { if } 0 \leqslant\left(1+\varrho_{t}\right) /\left(\gamma_{t} \epsilon_{t}\right) \tilde{h}_{t-1}-\tilde{h}_{t} \leqslant \delta^{h}\left(1+\varrho_{t}\right) /\left(\gamma_{t} \epsilon_{t}\right) \tilde{h}_{t-1} \text { and } z_{t}=0, \\ \kappa, & \text { otherwise. }\end{cases}
$$

The selling cost for the normalized problem is defined analogously. Finally, it is easy to show that with our change of variables, utility can be written as:

$$
u\left(c_{t}, x_{t} f_{t}+\left(1-x_{t}\right) h_{t}\right)={\frac{P_{t}}{q_{t}^{1-\alpha}}}^{1-\sigma} \frac{\left(\tilde{c}_{t}^{\alpha}\left(x_{t} \tilde{f}_{t}+\left(1-x_{t}\right) \tilde{h}_{t}\right)^{1-\alpha}\right)^{1-\sigma}}{1-\sigma} .
$$

Our computational strategy is a combination of the solution algorithms in Luengo-Prado (2006) and Díaz and LuengoPrado (2006). Because of the adjustment costs, we cannot use standard techniques that rely on differentiability. In brief, we solve a discretized version of the household problem using value function iteration.

To keep the problem tractable, we use 3 points to approximate each income shock and the house price shocks. The grids for both $\tilde{e}$ and $\tilde{h}$ start at zero. Upper bounds are chosen by trial and error. The grids are denser around certain neighborhoods where a significant fraction of households are concentrated. We start by solving the household problem with coarse grids and increase the number of points in each grid until our results do not change significantly. Solving the problem with a grid for $\tilde{e}$ instead of $\tilde{a}$ reduces the number of required points substantially because with a grid in $\tilde{a}$, one requires enough negative values to accommodate all possible house values in the grid for $\tilde{h}$. 


\section{D.2. Simulation strategy}

After solving the household problem for a given set of parameters, we generate shocks from the assumed distributions for 20,000 individuals. At the start of each simulation, all households are age 24 and have no assets. To ensure stationarity of the age distribution, we simulate 100 periods. Labor income shocks, moving shocks, mortality shocks and house price shocks are all idiosyncratic. With the optimal policy functions and the generated shocks, we can compute relevant statistics (e.g., the median wealth-to-earnings ratio by age). This statistics refer to the last period of each simulation, i.e., a cross section. Each experiment is repeated for 100 independent samples. The numbers we report, unless indicated, are averages of each relevant statistic across the 100 independent simulations (for the last period of each simulation). In our benchmark calibration, households are not linked dynastically. Any remaining assets are taxed away. In further exercises, we link households dynastically in the sense that when one household dies, a specific newborn inherits any remaining assets. Note, however, that we assume no intergenerational altruism so all bequests are accidental. Also, inheritances come in the form of liquid assets (i.e., houses are sold before a newborn receives the accidental bequest). Moreover, houses are liquidated before the house price shock for the next period is realized to ensure that bequests are nonnegative.

We conduct various exercises to determine the importance of a particular friction or parameter on the bias that may exist from using a rental equivalence method to value housing services. When doing so, we recalibrate the discount rate $\rho$, the weight of housing in the utility function, $1-\alpha$, and the value of the smallest house relative to permanent income, $\underline{\tilde{h}}$, to attain the same three targets (the homeownership rate, the median wealth-to-earnings ratio for workers and the median housing wealth to total wealth for homeowners).

To match the homeownership rate in the data, we need to impose a minimum house value relative to permanent income, $\underline{\tilde{h}}$. Our computation method does not allow us to consider an absolute minimum house value. Nevertheless, we think that the restriction we impose is not too stringent. For instance, if $\underline{\tilde{h}}=1.7$, the household must purchase a house worth at least 1.7 times their permanent income that period (i.e., the absolute minimum house value changes with permanent income). A possible interpretation is that households must purchase a house according to their means. A household making $\$ 100,000$ considers houses starting at $\$ 170,000$, while a household with an annual permanent income of $\$ 50,000$ considers houses worth $\$ 85,000$ and up.

\section{References}

Bajari, P., Benkard, C.L., Krainer, J., 2005. House prices and consumer welfare. Journal of Urban Economics 58 (3), $474-487$.

Budria, S., Díaz-Giménez, J., Quadrini, V., Ríos-Rull, J.-V., 2002. New facts on the distribution of earnings, income and wealth in the US. Federal Reserve Bank of Minneapolis Quarterly Review 21, 2-35.

Campbell, J., Cocco, J.F., 2003. Household risk management and optimal mortgage choice. Quarterly Journal of Economics 118 (4), $1149-1194$.

Carroll, C.D., 1997. Buffer-stock saving and the life cycle/permanent income hypothesis. Quarterly Journal of Economics 112 (1), 1-55.

Chambers, M., Garriga, C., Schlagenhauf, D.E., 2005. Accounting for changes in the homeownership rate. Mimeo, Florida State University.

Cocco, J.F., 2005. Portfolio choice in the presence of housing. Review of Financial Studies 18 (2), 535-567.

Cocco, J.F., Gomes, F.J., Maenhout, P.J., 2005. Consumption and portfolio choice over the life cycle. Review of Financial Studies 18 (2), $491-533$.

Díaz, A., Luengo-Prado, M.J., 2006. The wealth distribution with durable goods. Economics working papers we067027. Universidad Carlos III, Departamento de Economía.

Feenberg, D., Coutts, E., 1993. An introduction to the TAXSIM model. Journal of Policy Analysis and Management 12 (1), 189-194.

Fernández-Villaverde, J., Krueger, D., 2007. Consumption over the life cycle: Facts from consumer expenditure survey data. The Review of Economics and Statistics 89 (3), 552-565.

Flavin, M., Yamashita, T., 2002. Owner-occupied housing and the composition of the household portfolio over the life cycle. American Economic Review 92 (1), 345-362.

Gahvari, F., 1984. Incidence and efficiency aspects of differential taxation of industrial and residential capital in a growing economy. Journal of Public Economics 25 (1-2), 211-233.

Gervais, M., 2002. Housing taxation and capital accumulation. Journal of Monetary Economics 49 (7), 1461-1489.

Goetzmann, W.N., Spiegel, M.I., 2000. The policy implications of portfolio choice in underserved mortgage markets. Mimeo. Working paper No. 00-18, ICF, Yale.

Gourinchas, P.-O., Parker, J.A., 2002. Consumption over the life cycle. Econometrica 70 (1), 47-89.

Gruber, J.W., Martin, R.F., 2003. Precautionary savings and the wealth distribution with illiquid durables. Discussion paper No. 773 . Board of Governors of the Federal Reserve System, International Finance, September 2003.

Hall, R.E., Jorgenson, D.W., 1967. Tax policy and investment behavior. American Economic Review 57 (3), $391-414$.

Harding, J.P., Rosenthal, S.S., Sirmans, C., 2007. Depreciation of housing capital, maintenance, and house price inflation: Estimates from a repeat sales model. Journal of Urban Economics 61 (2), 193-217. 
Henderson, V., Ioannides, Y., 1983. A model of housing tenure choice. American Economic Review 73 (1), 98-113.

Himmelberg, C., Mayer, C., Sinai, T., 2005. Assessing high house prices: Bubbles, fundamentals and misperceptions. Journal of Economic Perspectives 19 (4), 67-92.

Li, W., Yao, R., 2007. The life-cycle effects of house price changes. Journal of Money, Credit and Banking 39 (6), $1375-1409$.

Linneman, P., Megbolugbe, I.F., Wachter, S.M., Chom, M., 1997. Do borrowing constraints change US homeownership rates? Journal of Housing Economics 6 (4), 318-333.

Luengo-Prado, M.J., 2006. Durables, nondurables, down payments and consumption excesses. Journal of Monetary Economics 53 (1), $1509-1539$.

McGrattan, E.R., Prescott, E.C., 2005. Taxes, regulations, and the value of US and UK corporations. Review of Economic Studies 72 (3), 767-796.

Mendoza, E.G., Milesi-Ferretti, G.M., Asea, P., 1997. On the ineffectiveness of tax policy in altering long-run growth: Harberger's superneutrality conjecture. Journal of Public Economics 66 (1), 99-126.

Munnell, A.H., Soto, M., 2005. What replacement rates do households actually experience in retirement? Working paper No. 2005-10, CRR.

Ortalo-Magné, F., Rady, S., 1999. Boom in, bust out: Young households and the housing price cycle. European Economic Review 43 (4), $755-766$.

Ortalo-Magné, F., Rady, S., 2002. Tenure choice and the riskiness of non-housing consumption. Journal of Housing Economics 11 (3), $266-279$.

Poole, R., Ptacke, F., Verbrugge, R., 2005. Treatment of owner-occupied housing in the CPI. Mimeo, BLS.

Poterba, J.M., 1984. Tax subsidies to owner-occupied housing: An asset-market approach. Quarterly Journal of Economics 99 (4), $729-752$.

Prescott, E.C., 1997. On defining real consumption. Federal Reserve Bank of St. Louis Review 79 (May/June), 47-54.

Prescott, E.C., 2004. Why do Americans work so much more than Europeans? Federal Reserve Bank of Minneapolis Quarterly Review (July), $2-13$.

Quercia, R.G., McCarthy, G.W., Watcher, S.F., 2000. The impacts of affordable lending efforts on homeownership rates. Manuscript, Federal Home Loan Mortgage Corporation.

Sinai, T., Souleles, N.S., 2005. Owner-occupied housing as a hedge against rent risk. Quarterly Journal of Economics 120 (2), $763-789$.

Skinner, J., 1996. The dynamic efficiency cost of not taxing housing. Journal of Public Economics 59 (3), 397-417.

Storesletten, K., Telmer, C., Yaron, A., 2004. Consumption and risk sharing over the life cycle. Journal of Monetary Economics 51 (3), $609-633$.

Verbrugge, R., 2003. The puzzling divergence of aggregate rents and user costs, 1978-2001. Mimeo, PINR, BLS.

Yao, R., Zhang, H.H., 2005. Optimal consumption and portfolio choices with risky labor income and borrowing constraints. Review of Financial Studies 18 (1), 197-239. 